\title{
PERCEPCIJA STRUČNJAKA O SVRSISHODNOSTI SUSTAVA MALOLJETNIČKOG PRAVOSUĐA
}

\author{
Sabina Mandić, mag. soc. ped.* \\ Doc. dr. sc. Dora Dodig Hundrić** \\ Izv. prof. dr. sc. Neven Ricijašs*** \\ Mirta Kuharić, dipl. iur.****
}

\author{
UDK 343.91-053.55(4) \\ https://doi.org/10.30925/zpfsr.39.3.4 \\ Ur.: 2. svibnja 2018. \\ Pr.: 13. rujna 2018. \\ Prethodno priopćenje
}

\section{Sažetak}

U ovom je radu prikazan dio rezultata istraživanja koje je provelo Povjerenstvo za praćenje $i$ unaprjeđivanje rada tijela kaznenog postupka i izvršavanja maloljetničkih sankcija koje je osnovao ministar nadležan za poslove pravosuđa prema članku 127. stavku 1. Zakona o sudovima za mladež. Istraživanje je usmjereno na stjecanje uvida u percepciju pravosudnog sustava i međuresornu suradnju između državnih odvjetništava, sudova za mladež i centara za socijalnu skrb u kaznenim postupcima prema maloljetnim počiniteljima kaznenih djela. $U$ radujenaglasakna dijelu rezultata usmjerenih na različite aspekte funkcioniranja maloljetničkog pravosuđa. Glavni je cilj rada stjecanje uvida u perspektivu stručnjaka o svrsishodnosti sustava maloljetničkog pravosuđa, te istraživanje eventualnih razlika u njihovoj percepciji s obzirom na područje rada. Uzorak je obuhvatio 309 sudionika iz cijele Hrvatske, od čega 98 zaposlenih u državnim odvjetništvima, 82 na sudovima te 129 u centrima za socijalnu skrb. Rezultati ukazuju na umjereno zadovoljstvo funkcioniranjem maloljetničkog pravosuđa $i$ pozitivnu percepciju hrvatskoga sustava, posebno u aspektima temeljnih načela $i$ sadržaja zakonskih propisa te izricanjem/izvršavanjem izvaninstitucionalnih odgojnih mjera. Najmanji stupanj zadovoljstva izražen je u području izricanja/ izvršavanja poluinstitucionalnih i institucionalnih maloljetničkih sankcija, pri čemu djelatnici državnih odvjetništava iskazuju najmanje zadovoljstvo, odnosno izražavaju najkritičniji stav, posebno u odnosu na djelatnike sudova za

* Sabina Mandić, mag. soc. ped., asistentica na Odsjeku za poremećaje u ponašanju Edukacijskorehabilitacijskog fakulteta Sveučilišta u Zagrebu; sabina.mandic@erf.hr.

** Dr. sc. Dora Dodig Hundrić, docentica na Odsjeku za poremećaje u ponašanju Edukacijskorehabilitacijskog fakulteta Sveučilišta u Zagrebu; dora.dodig@erf.hr.

*** Dr. sc. Neven Ricijaš, izvanredni profesor na Odsjeku za poremećaje u ponašanju Edukacijskorehabilitacijskog fakulteta Sveučilišta u Zagrebu; član Povjerenstva za praćenje i unaprjeđivanje rada tijela kaznenog postupka i izvršavanja maloljetničkih sankcija; neven.ricijas@erf.hr.

**** Mirta Kuharić, dipl. iur., zamjenica Glavnog državnog odvjetnika - Kazneni odjel; predsjednica Povjerenstva za praćenje i unaprjeđivanje rada tijela kaznenog postupka i izvršavanja maloljetničkih sankcija; mirta.kuharic@dorh.hr. 
mladež. Rezultati su tumačeni u kontekstu potencijalnih praktičnih implikacija i mogućnosti unaprjeđenja sustava, ali i kao temelj za daljnja istraživanja ove teme.

Ključne riječi: maloljetničko pravosuđe, Zakon o sudovima za mladež, centar za socijalnu skrb, državno odvjetništvo, sud za mladež.

\section{UVOD}

U posljednjih tridesetak godina pitanja koja se odnose na problematiku maloljetničke delinkvencije privlače interes sve većeg broja znanstvenika i stručnjaka u praksi. S jedne strane, određeni broj stručnjaka i političara, ali i šira javnost kritiziraju postojeći sustav reakcije države na maloljetničku delinkvenciju te se zalažu za strože sankcije prema maloljetnicima. ${ }^{1}$ Usporedno s time, jača interes za promicanjem dječjih prava i vrijednosti na međunarodnoj razini, što se u ovom kontekstu odnosi na prava djece u okviru pravosudnog sustava. ${ }^{2}$ Uz Konvenciju o pravima djeteta ${ }^{3}$ kao temeljnim dokumentom, implementiraju se brojne međunarodne preporuke i standardi pravosuđa prilagođenog djeci koji imaju za cilj osigurati prava djece u svim fazama kaznenog postupka. U tom kontekstu, pravosuđe prilagođeno djeci pojam je koji se koristi u novije vrijeme i podrazumijeva pravosudne sustave koji jamče učinkovitu provedbu svih dječjih prava prije, tijekom i nakon pravosudnog postupka, pri čemu se odnosi na maloljetne osobe koje su počinitelji kaznenih djela/prekršaja, ali i na predmete kaznenopravne zaštite djece. Pritom je važno uzeti u obzir da se djetetom u međunarodnom kontekstu smatra osoba mlađa od 18 godina života, što ne treba miješati s maloljetništvom kao zakonski definiranom dobnom skupinom koju u pojedinim državama najčešće definira prag kaznene odgovornosti. ${ }^{4} \mathrm{Uz}$ Konvenciju o pravima djeteta, važan dokument za naše područje je i Europska konvencija o ostvarivanju dječjih prava ${ }^{5} \mathrm{u}$ kojoj se naglašava važnost promicanja najboljeg interesa djece i ostvarivanja njihovih prava.

Ostvarivanje dječjih prava u području maloljetničkog pravosuđa promovira se i osigurava brojnim dokumentima Ujedinjenih naroda (u daljnjem tekstu UN) koji čine

1 Radić, I., Hrvatski sustav maloljetničkih sankcija: trenutačno stanje i prijedlozi za promjenu, Hrvatski ljetopis za kaznene znanosti i praksu, vol. 24, 1/2017, str. 84.

2 Nacionalna strategija za prava djece u Republici Hrvatskoj za razdoblje od 2014. do 2020. godine (2014), Ministarstvo socijalne politike i mladih, objavljeno na : <https://vlada.gov.hr/ UserDocsImages/ZPPI/Strategije \%20-\%20OGP/socijalna\%20politika/NACIONALNA $\% 20$ STRATEGIJA\%20ZA\%20PRAVA\%20DJECE\%20U\%20RHZA\%20RAZDOBLJE\%20 OD\%202014.\%20DO\%202020.\%20GODINE\%5B1\%5D.pdf>, zadnji put posjećeno 1. ožujka 2018.

3 Konvencija o pravima djeteta (1989), objavljeno na: <https://www.unicef.hr/wp-content/ uploads/2017/05/Konvencija_20o_20pravima_20djeteta_full.pdf $>$, zadnji put posjećeno 1 . ožujka 2018.

4 Ricijaš, N., Dobre prakse i izazovi u kontekstu maloljetničke delinkvencije u Hrvatskoj, objavljeno u: Kovačević, R. i sur. (ur.): Maloljetnička delinkvencija - dijalog, razmjena iskustava i znanja, OFF SET Tuzla, Bosna i Hercegovina, 2017, str. 123-144.

5 Zakon o potvrđivanju Europske konvencije o ostvarivanju dječjih prava, NN 1/2010. 
temelje zakonodavstava usmjerenih prema maloljetnicima u gotovo svim europskim državama, od kojih su najvažniji:

- Standardna minimalna pravila UN-a za maloljetničko pravosuđe („Pekinška pravila“, 1985) ${ }^{6}$ kojima je cilj promicanje dobrobiti mladih u najvećoj mogućoj mjeri, što će posljedično smanjiti potrebu za intervencijama u području maloljetničkog pravosuđa;

- Pravila UN-a za zaštitu maloljetnika lišenih slobode („Pravila iz Havane“, $1990)^{7} \mathrm{i}$

- Smjernice UN-a za prevenciju maloljetničke delinkvencije („Rijadske smjernice“", 1990). ${ }^{8}$

„Pekinška pravila“ daju državama članicama UN-a osnovni okvir za postupanje u području maloljetničkog pravosuđa, dok „Rijadske smjernice“ ističu potrebu izrade standarda za prevenciju maloljetničke delinkvencije. U oba navedena dokumenta istaknuta je važnost ponajprije prevencije maloljetničke delinkvencije, ali i razvoj izvaninstitucionalnih usluga za maloljetnike u zajednici. ${ }^{9}$

Odbor ministara Vijeća Europe je na europskoj razini donio niz preporuka u cilju unaprjeđivanja maloljetničkog pravosuđa, a sve odredbe i pravila gore navedenih dokumenata i preporuka, ali i mnogih drugih koji utvrđuju prava i položaj djeteta u kaznenopravnom postupku, objedinjena su u Smjernicama Odbora ministara Vijeća Europe o pravosuđu prilagođenom djeci. U tim Smjernicama generirano je pet temeljnih načela koja se trebaju poštovati, a to su: (1) sudjelovanje djeteta koje se odnosi na pravo djece da budu obaviještena o svojim pravima, da ih se pita za mišljenje te da se prema njima treba odnositi kao prema nositeljima vlastitih prava; (2) najbolji interesi djeteta koje se odnosi na to da se o njima mora voditi računa u svim slučajevima kada je dijete uključeno, ali naglašava se i važnost multidisciplinarnog pristupa radi najboljeg interesa djeteta; (3) dostojanstven odnos prema djetetu koje se odnosi na dostojanstveno postupanje bez obzira na način na koji je dijete došlo $\mathrm{u}$ kontakt s pravosudnim postupkom; (4) zaštita djeteta od diskriminacije koje se odnosi na zaštitu djeteta od diskriminacije po bilo kojoj osnovi (boja kože, spol itd.) te (5) vladavina prava koja se odnosi na poštovanje elemenata propisnog postupka, kao što su primjerice načela zakonitosti i razmjernosti, pravo na pošteno suđenje, pravo na

6 Standardna minimalna pravila Ujedinjenih naroda za maloljetničko pravosuđe („Pekinška pravila“, 1985), (A/RES/40/33), objavljeno na: <http://www.un.org/documents/ga/res/40/ a40r033.htm>, zadnji put posjećeno 1. ožujka 2018.

7 Pravila Ujedinjenih naroda za zaštitu maloljetnika lišenih slobode („Pravila iz Havane“, 1990), (A/RES/45/113), objavljeno na: <http://www.un.org/documents/ga/res/45/a45r113.htm>, zadnji put posjećeno 1. ožujka 2018.

8 Smjernice Ujedinjenih naroda za prevenciju maloljetničke delinkvencije („Rijadske smjernice“, 1990), (A/RES/45/112), objavljeno na: <http://www.un.org/documents/ga/res/45/a45r112. htm>, zadnji put posjećeno 1. ožujka 2018.

9 Štabi, M., Standardna minimalna pravila Ujedinjenih naroda za maloljetničko pravosuđe („Pekinška pravila“, 1985) (A/RES/40/33) i Smjernice Ujedinjenih naroda za prevenciju maloljetničke delinkvencije (,Rijadske smjernice“, 1990) (A/RES/45/112), Dijete i društvo: časopis za promicanje prava djeteta, vol. 12, 1/2 / 2010., str. 295-296. 
odvjetnika i slično. ${ }^{10} \mathrm{U}$ hrvatskom kontekstu važno je nadovezati se i na Nacionalnu strategiju za prava djece u Republici Hrvatskoj za razdoblje od 2014. do 2020. godine (u daljnjem tekstu Nacionalna strategija za prava djece) ${ }^{11}$, u kojoj je osiguravanje usluga i sustava prilagođenih djeci u sustavu pravosuđa definirano kao prvi strateški cilj. Kao neki od ciljeva unutar sustava pravosuđa navode se i unaprjeđivanje brzine i učinkovitosti postupaka prema djeci koja se javljaju kao počinitelji kaznenih djela, sustavno praćenje učinkovitosti i razvijanje indikatora učinkovitosti primijenjenih kaznenopravnih sankcija prema djeci, unaprjeđivanje rada kaznenih i prekršajnih sudova, sustavno unaprjeđivanje modaliteta izvršavanja sankcija i programa intervencija prema djeci te sustavno unaprjeđivanje kompetencija svih stručnjaka pravne i izvanpravne struke uključenih u postupke u kojima sudjeluju djeca.

\section{KAZNENOPRAVNI POLOŽAJ MALOLJETNIKA U REPUBLICI HRVATSKOJ}

U Republici Hrvatskoj, analizirajući relevantne nacionalne zakonske dokumente, vidljivo je kako maloljetničko pravosuđe počiva na brojnim načelima definiranim Kaznenim zakonom ${ }^{12}$ (u daljnjem tekstu KZ/11), Zakonom o sudovima za mlade $\check{z}^{13}$ (u daljnjem tekstu ZSM/11) i Zakonom o izvršavanju sankcija izrečenih maloljetnicima za kaznena djela i prekršaje ${ }^{14}$ (u daljnjem tekstu ZISIM/12), a čiji su „temelji“ vidljivi u gore navedenim međunarodnim dokumentima. Kazneni zakon u svojim temeljnim odredbama navodi brojna načela koja se trebaju primjenjivati prema svim skupinama počinitelja kaznenih djela, pa tako i prema maloljetnicima. Kao prvo, važno je navesti načelo zakonitosti (čl. 2. KZ/11), načelo primjene blažeg zakona i vremensko važenje kaznenog zakonodavstva (čl. 3. KZ/11) te načelo krivnje koje se navodi u čl. 4. KZ/11. Slijedom navedenih načela, ZSM navodi kako kazneni postupak prema maloljetniku mora biti hitan (čl. 4. i 59. ZSM/11), te kako se postupanje prema maloljetniku i provedba izrečenih sankcija (načelo pravovremenosti sankcije) treba provesti $\mathrm{u}$ vremenu dok je njihov utjecaj odlučujući za maloljetnika (čl. 8. ZSM/11). Nadalje, brojni članci u ZSM-u ${ }^{15}$ navode kako postupanje prema maloljetniku i izrečene mu sankcije trebaju biti svrhovite, odnosno da se tim postupcima treba ostvariti svrha maloljetničkih sankcija propisana čl. 6. ZSM-a. Načelo tajnosti očituje se u nekoliko segmenata, pa tako izvidi kaznenih djela i cijeli postupak prema maloljetniku moraju biti tajni (čl. 60. ZSM/11), presuda ne smije biti javno objavljena (čl. 34. ZSM/11), a ZISIM/12 u čl. 4. navodi kako su podatci o maloljetniku i o tijeku izvršavanja sankcije tajni. Sudovi trebaju postupati prema načelu postupnosti (sankcije), odnosno

10 Smjernice Odbora ministara Vijeća Europe o pravosuđu prilagođenom djeci, objavljeno na: $<$ https://rm.coe.int/16806a450a $>$, zadnji put posjećeno 1. ožujka 2018.

11 Nacionalna strategija za prava djece u Republici Hrvatskoj za razdoblje od 2014. do 2020. godine, op. cit. u bilj. 2.

12 Kazneni zakon, NN 125/2011., 144/2012., 56/2015., 61/2015., 101/2017.

13 Zakon o sudovima za mladež, NN 84/2011., 143/2012., 148/2013., 56/2015.

14 Zakon o izvršavanju sankcija izrečenih maloljetnicima za kaznena djela i prekršaje, NN $133 / 2012$.

15 Vidi: čl. 7., čl. 8., čl. 9., čl. 11., čl. 12., čl. 13., čll 17., čl. 18. ZSM/11. 
da onda kada je to s obzirom na ličnost maloljetnika i na okolnosti počinjenja djela moguće, prema maloljetniku prvo izriču blaže sankcije, a potom, postoji li potreba, promijene ili obustave izvršenje sankcije (čl. 7. st. 2., st. 3., st. 4. ZSM/11), što se nadovezuje na načelo promjenjivosti sankcije čija je primjena jasno propisana čl. 99. ZSM/11 (pozivajući se na čl. 15., čl. 16., čl. 17., čl. 18. i čl. 20. ZSM/11). U Glavi II. ZISIM-a definirana su temeljna načela izvršavanja sankcija u kojima se navodi kako je maloljetniku tijekom izvršavanja sankcije zajamčeno poštovanje ljudskog dostojanstva, zabranjena je diskriminacija po bilo kojoj osnovi, te je zabranjeno тис̌enje, zlostavljanje ili ponižavanje maloljetnika (čl. 5. ZISIM/12). Maloljetniku se osigurava i izvršavanje sankcije temeljeno na pojedinačnom programu postupanja koji je prilagođen njegovim kriminogenim rizičnim čimbenicima (čl. 7. ZISIM/12), te mu se treba osigurati pravodobna priprema za otpuštanje iz odgojne ustanove, posebne odgojne ustanove, odgojnog zavoda ili kaznionice (čl. 8. ZISIM/12). Sva navedena načela iznimno su važna u predmetima u koje su uključeni maloljetnici, a u ovom istraživanju usmjerili smo se na četiri načela: načelo hitnosti postupanja, načelo pravovremenosti postupanja, načelo postupnosti i načelo promjenjivosti sankcije, kao komponente koje su uvelike determinirane međuresornom suradnjom različitih stručnjaka i službi (policija, državno odvjetništvo, sustav socijalne skrbi te sudovi).

Uz navedene međunarodne dokumente i Nacionalnu strategiju za prava djece, Kazneni zakon i Zakon o sudovima za mladež, te uvažavajući ranije navedena načela, pri definiranju kaznenopravnog položaja maloljetnika u Hrvatskoj polazi se od Ustava Republike Hrvatske kao temeljnoga dokumenta kojim se određuju prava hrvatskih građana i koji, između ostaloga, u čl. 65. definira kako je dužnost svih da štite djecu $i$ nemoćne osobe ${ }^{16}$. U ovom radu pojmovi dijete i maloljetnik koristit će se iz perspektive hrvatskoga kazneno-pravnog okvira vezano za počinitelje kaznenih djela, odnosno koristit će se terminološka određenja KZ-a i ZSM-a, na način da se djetetom smatra osoba koja u vrijeme počinjenja kaznenog dijela nije navršila 14 godina života (čl. 7. st. 1. KZ/11), mlađim maloljetnikom osoba koja je u vrijeme počinjenja kaznenog djela navršila 14 godina života, a nije navršila 16 godina života, starijim maloljetnikom osoba koja je u vrijeme počinjenja kaznenog djela navršila 16 godina života, a nije navršila 18 godina života (čl. 5. st. 2., st. 3. ZSM/11), dok se mlađim punoljetnikom smatra osoba koja je u vrijeme počinjenja kaznenog djela navršila 18 godina života, a nije navršila 21 godinu života (čl. 2. ZSM/11). ${ }^{17}$ Uvažavanje razvojne specifičnosti maloljetnika vidljivo je iz činjenice da zakonodavac maloljetne počinitelje kaznenih djela izdvaja iz skupine odraslih počinitelja, te se prema njima postupa prema Zakonu o sudovima za mladež kao lex specialis-u. Zakon, materija koju regulira i pojedina zakonska rješenja usvojeni su 1997. godine u prvom Zakonu o sudovima za mladež prema načelu primum non nocere (prijevod: prije svega ne povrijediti) ${ }^{18}$, koji je bio

16 Ustav Republike Hrvatske, NN 56/1990., 135/1997., 8/1998., 113/2000., 124/2000., 28/2001., 41/2001., 55/2001., 76/2010., 85/2010., 05/2014.

$17 \mathrm{Za}$ razliku od predmeta prema maloljetnim počiniteljima kaznenih djela, u predmetima kaznenopravne zaštite djece, djetetom se smatra osoba koja u vrijeme počinjenja kaznenog djela nije navršila 18 godina života (čl. 113. st. 2. ZSM/11).

18 Rittossa, D. i Božićević Grbić, M., Zakon o sudovima za mladež - reformski zahvati i praktične dileme, Hrvatski ljetopis za kazneno pravo i praksu, vol. 19, 2/2012., str. 630. 
na snazi sve do 2011. godine kada je na snagu stupio novi ZSM. Njime je uređen materijalni i procesno pravni položaj maloljetnih i mlađih punoljetnih počinitelja kaznenih djela, kao i kaznenopravna zaštita djece te je glavni izvor maloljetničkoga kaznenog prava u Hrvatskoj. ${ }^{19}$

\section{KAZNENOPRAVNI POSTUPAK PREMA MALOLJETNIM POČINITELJIMA KAZNENIH DJELA}

Kazneni postupak prema maloljetnim počiniteljima kaznenih djela relativno je složen, kao i zakonska regulativa oko načina izvršavanja sankcija. ${ }^{20}$ Institucije koje čine okosnicu postupanja prema maloljetnim počiniteljima kaznenih djela su policija, državno odvjetništvo, sud i centri za socijalnu skrb.

Policija je prva institucija s kojom se maloljetni počinitelj kaznenog djela susreće. Izvide kaznenih djela u postupku prema maloljetniku provode policijski službenici za mladež ili drugi policijski službenici ako zbog okolnosti slučaja ne mogu postupati policijski službenici za mladež (čl. 69. ZSM/11). Zatim, postupajući po zaprimljenoj kaznenoj prijavi, državno odvjetništvo odlučuje o (ne)postojanju osnove za vođenje kaznenog postupka prema maloljetniku, odnosno o (ne)postojanju osnovane sumnje, o čemu ovisi hoće li kaznena prijava biti odbačena, hoće li se prema maloljetniku primijeniti oportunitet ili će se provesti pripremni postupak. Ako kaznena prijava nije odbačena iz razloga propisanih u čl. 206. Zakona o kaznenom postupku ${ }^{21}$ (u daljnjem tekstu ZKP), a radi se o kaznenom djelu za koje je propisana kazna zatvora u trajanju do pet godina ili novčana kazna, tri su mogućnosti postupanja državnog odvjetnika u odnosu na primjenu načela oportuniteta. Prva je da državno odvjetništvo odluči da, s obzirom na narav počinjenog kaznenog djela, raniji život maloljetnika i njegove osobne i obiteljske prilike, ne bi bilo svrhovito vođenje kaznenog postupka prema maloljetniku (čl. 71. ZSM, tzv. bezuvjetni oportunitet). Druga je da se odluka o nepokretanju postupka prema maloljetniku donese nakon što maloljetnik izvrši naložene mu obveze (čl. 72. ZSM, tzv. uvjetovani oportunitet), dok je treća mogućnost donošenje odluke o nesvrhovitosti vođenja kaznenog postupka prema maloljetniku za drugo kazneno djelo (s obzirom na težinu, narav i okolnosti njegovog počinjenja) kad je maloljetnik već ranije odlukom centra za socijalnu skrb smješten u ustanovu socijalne skrbi, kada je izvršenje kazne ili odgojne mjere u tijeku ili kad su ove sankcije pravomoćno izrečene (čl. 73. ZSM). I konačno, državno odvjetništvo može donijeti odluku (rješenje) o provođenju pripremnog postupka prema maloljetniku za kaznena djela za koja se prema odredbama ZKP-a provodi istraga (čl. 75. ZSM) ili podnijeti obrazloženi prijedlog za izricanje maloljetničke sankcije (tzv. neposredni prijedlog iz čl. 82. ZSM).

19 Carić, A. i Kustura, I., Kamo ide hrvatsko maloljetničko kazneno zakonodavstvo? - 1. dio, Zbornik radova Pravnog fakulteta u Splitu, vol. 47, 3/2010., str. 605.

20 Ricijaš, N., Priručnik za edukaciju - Procjena, planiranje i izvještavanje u izvršavanju maloljetničkih alternativnih sankcija, Zagreb, Ministarstvo socijalne politike i mladih, 2012.

21 Zakon o kaznenom postupku, NN 152/2008., 76/2009., 80/2011., 121/2011., 91/2012., 143/2012., 56/2013., 145/2013., 152/2014., 70/2017. 
Centri za socijalnu skrb su uključeni u postupak prema maloljetnim počiniteljima kaznenih djela od samog početka ${ }^{22}$, te su u kontaktu s policijom, državnim odvjetništvom, sudovima i ostalim ustanovama i institucijama koje sudjeluju u postupku i/ili izvršavanju maloljetničkih sankcija. Od centara za socijalnu skrb u različitim fazama kaznenog postupka mogu se tražiti izvješća o specifičnim okolnostima (primjerice čl. 65. st. 1., čl. 71., čl. 78. st. 2., st. 3. ZSM/11), izvješća o provedbi alternativnih mjera u prethodnom postupku (čl. 72. st. 2. ZSM/11), dok kod izvršavanja alternativnih mjera i sankcija ${ }^{23}$ imaju obvezu programiranja izvršavanja tih mjera i sankcija ${ }^{24}$ kao i obvezu izvještavanja o njihovom provođenju, što je definirano ZISIM-om (primjerice čl. 12., čl. 13., čl. 35. ZISIM/12) te Pravilnikom o načinu izvršavanja odgojnih mjera posebne obveze, upućivanje u disciplinski centar, pojačana briga i nadzor, pojačana briga i nadzor uz dnevni boravak u odgojnoj ustanovi, upućivanje u odgojnu ustanovu i upućivanje u posebnu odgojnu ustanovu ${ }^{25}$ (u daljnjem tekstu Pravilnik o načinu izvršavanja odgojnih mjera).

U kaznenim predmetima prema maloljetnicima nadležni su sudovi za mladež (čl. 35. vezano uz čl. 37. st. 1. i st. 2. ZSM/11), koji su kao i centri za socijalnu skrb uključeni u postupak od samog početka. Tako se prema čl. 63. st. 1. ZSM-a pri uhićenju maloljetnika odmah obavještava sudac za mladež, koji će po nalogu državnog odvjetnika ispitati uhićenog maloljetnika te odlučiti o određivanju pritvora, istražnog zatvora ili njegovom puštanju na slobodu (čl. 63. st. 2. i st. 3. ZSM/11). Sudac za mladež određuje, produljuje i ukida mjere opreza (čl. 64. ZSM/11) i mjeru privremenog smještaja prema maloljetniku (čl. 65. st. 2. ZSM/11). Suci za mladež provode dokazna ročišta (u vezi s čl. 77. st. 2. ZSM/11), ispituju osnovanost prijedloga za izricanje maloljetničke sankcije (čl. 83. ZSM), određuju sjednicu vijeća i zakazuju raspravu. Sud za mladež vrši i nadzor nad izvršavanjem izrečenih odgojnih mjera (čl. 96. st. 1. ZSM/11), a u članku 98. ZSM-a opisan je modalitet vršenja nadzora nad izvršavanjem izvanzavodskih odgojnih mjera te je definirana suradnja svih triju institucija i to na način da centri za socijalnu skrb redovito izvještavaju sud koji je izrekao mjeru i nadležno državno odvjetništvo o tijeku izvršavanja odgojnih mjera.

Pravilnik o radu stručnih suradnika izvanpravne struke na poslovima delinkvencije mladih i kaznenopravne zaštite djece u državnim odvjetništvima i na

22 Kovačević, M., Osnovni modeli maloljetničkog pravosuđa s osvrtom na ulogu i položaj socijalnog rada, Ljetopis socijalnog rada, vol. 20, 2/2013., str. 302.

23 Alternativne mjere u hrvatskom kontekstu jesu one mjere koje određuje državno odvjetništvo ili sud tijekom kaznenog postupka i izvršavaju se u zajednici. Alternativne sankcije odnose se na izrečene sankcije koje je izrekao sud za mladež ili prekršajni sud, a koje se također izvršavaju u zajednici i alternativa su institucionalizaciji. Vidi detaljnije: Ricijaš, N. (2012), op. cit u bilj. 20, str. 8.

24 ChildONEurope (2013), Complementarities and synergies between juvenile justice and social services sector: The proceedings of the ChildONEurope Seminar on Juvenile Justice, objavljeno na: <http://www.childoneurope.org/issues/publications/coe\%206_web.pdf $>$, zadnji put posjećeno 5. studenog 2016. Vidi više: Ricijaš, N. (2012), op. cit. u bilj. 20 , str. 5-10.

25 Pravilnik o načinu izvršavanja odgojnih mjera posebne obveze, upućivanje u disciplinski centar, pojačana briga i nadzor, pojačana briga i nadzor uz dnevni boravak u odgojnoj ustanovi, upućivanje u odgojnu ustanovu i upućivanje u posebnu odgojnu ustanovu, NN 22/2013. 
sudovima ${ }^{26}$ propisuje poslove stručnih suradnika izvanpravne struke u državnim odvjetništvima i na sudovima koji svojim specifičnim znanjima o maloljetnim počiniteljima kaznenih djela pomažu državnim odvjetnicima i sucima, koristeći pritom i saznanja dobivena iz podataka centara za socijalnu skrb u svim fazama postupka. ${ }^{27}$ Iz svega prethodno navedenog, evidentno je kako su državna odvjetništva, centri za socijalnu skrb i sudovi za mladež u predmetima maloljetničkog pravosuđa, od prvog kontakta s maloljetnikom u stalnoj suradnji radi sveobuhvatnijeg i kvalitetnijeg postupanja prema maloljetniku, ali i pravodobnog reagiranja i primjene sankcija onda kada one imaju odlučujući utjecaj na maloljetnika.

Kazneni postupak prema maloljetnicima uređen je ZSM-om od čl. 48. do čl. 93., te se vodi pred sudom za mladež kao nadležnim sudom za postupanje prema maloljetnicima (čl. 35. ZSM/11). Postupak prema maloljetnicima manje je formalan i više fleksibilan nego u predmetima protiv odraslih počinitelja kaznenih djela, a sudac za mladež ima široke ovlasti da u pojedinim etapama postupka odstupi od „krute“ procedure redovitoga kaznenog postupka te da ga prilagodi potrebama pojedinog slučaja. ${ }^{28}$ Zaštitni model hrvatskoga maloljetničkog pravosuđa vidljiv je i u nekim od općih obilježja kaznenog postupanja, kao što je upoznavanje ličnosti maloljetnika i njegovih osobnih i obiteljskih prilika koje su važne za donošenje niza odluka od početka postupka pa sve do kraja izvršavanja sankcije. Primjerice, odluka o primjeni načela svrhovitosti, bilo da je donosi državni odvjetnik, predsjednik vijeća za mladež ili vijeće za mladež ne može biti donesena ako se ne raspolaže s dovoljno informacija koje se odnose na ličnost maloljetnika, njegove osobne, obiteljske i socijalne prilike. Nadalje, odredbama ZSM-a propisana je mogućnost donošenja odluke po kaznenoj prijavi prema maloljetnim počiniteljima kaznenih djela za koja je propisana kazna zatvora u trajanju do pet godina ili novčana kazna već u prethodnom postupku, primjenom načela svrhovitosti (oportuniteta) prema maloljetniku, uz uvjet da postoji osnovana sumnja da je maloljetnik to kazneno djelo i počinio. Načelo svrhovitosti osim u prethodnom postupku može primijeniti i sud u postupku pred vijećem za mladež.

\section{MALOLJETNIČKE SANKCIJE I NAČELA UČINKOVITOG MALOLJETNIČKOG PRAVOSU円A}

Kao što smo vidjeli iz prethodnog teksta, tijekom cijelog su kaznenopravnog postupka prema maloljetnim počiniteljimakaznenih djela na prvom mjestu brigaizaštita maloljetnika. Naglasak je i na njihovoj što manjoj stigmatizaciji i individualiziranom pristupu, a to se usmjerenje ogleda i u odabiru sankcije. Maloljetnim počiniteljima kaznenih djela se, kako propisuje čl. 5. st. 1. ZSM-a, izriču odgojne mjere (sudski

26 Pravilnik o radu stručnih suradnika izvanpravne struke na poslovima delinkvencije mladih i kaznenopravne zaštite djece u državnim odvjetništvima i na sudovima, NN 84/2011., 143/2012.

27 Singer, M., Kaznenopravna odgovornost i zaštita mladeži, Zagreb, Nakladni zavod Globus i Sveučilište u Zagrebu, 1998.

28 Carić, A. i Kustura, I., Kamo ide hrvatsko maloljetničko kazneno zakonodavstvo? - 2. dio, Zbornik radova Pravnog fakulteta u Splitu, vol. 47, 4/2010., str. 779-791. 
ukor, posebne obveze, pojačana briga i nadzor (u daljnjem tekstu PBIN), pojačana briga i nadzor uz dnevni boravak u odgojnoj ustanovi, upućivanje u disciplinski centar, upućivanje u odgojnu ustanovu, upućivanje u odgojni zavod, upućivanje u posebnu odgojnu ustanovu) i maloljetnički zatvor, a uz posebne uvjete predviđene ovim zakonom, i sigurnosne mjere. U čl. 5. propisano je i kojoj skupini maloljetnika se mogu izreći određene sankcije. Tako se prema mlađem maloljetniku mogu izreći odgojne i sigurnosne mjere (čl. 5. st. 2. ZSM/11), dok se starijem maloljetniku može izreći i maloljetnički zatvor (čl. 5. st. 3. ZSM/11).

Republika Hrvatska ima primjeren pravni okvir koji uzima u obzir specifičnosti maloljetnika u različitim etapama postupanja. Nacionalnom strategijom za prava djece prepoznata je važnost unaprjeđivanja cijelog sustava pravosuđa vezano uz maloljetnike (ali i djecu žrtve kaznenih djela) osuvremenjivanjem zakona i njihovog usklađivanja s međunarodnim preporukama i smjernicama, ali i važnost kvalitetne suradnje među ključnim institucijama. Kvalitetna pravna regulativa nedvojbeno je preduvjet za primjereno postupanje prema maloljetnicima, no ono što je još važnije jest njihova primjena u svakodnevnoj praksi. O tomu najviše znaju oni koji čine okosnicu maloljetničkog pravosuđa, tj. stručnjaci zaposleni u ranije navedenim institucijama. Njihov doživljaj različitih aspekata maloljetničkog pravosuđa utječe na njihov rad i suradnju, stoga je Povjerenstvo za praćenje $i$ unaprjeđivanje rada tijela kaznenog postupka i izvršavanja maloljetničkih sankcija (osnovano na temelju čl. 127. st. 1. ZSM-a) pri Ministarstvu pravosuđa RH provelo istraživanje radi identificiranja primjera dobre prakse, kao i izazova u području maloljetničkog pravosuđa. Kako bi se moglo uopće govoriti o primjerima dobre i učinkovite prakse, prvo je potrebno utvrditi kriterije dobre prakse, kojima se može pristupiti iz više perspektiva. Na te kriterije u području maloljetničkog pravosuđa može se gledati iz tri međusobno povezane i neodvojive perspektive, a to su: (1) perspektiva usuglašenosti sustava maloljetničkog pravosuđa s međunarodnim dokumentima, standardima i preporukama, (2) pravna $i$ teorijska perspektiva te (3) znanstveno-empirijska perspektiva. Prva perspektiva obuhvaća ranije opisane međunarodne dokumente koji postavljaju minimalne standarde i preporuke za nacionalne politike na području maloljetničkog pravosuđa. Sljedeća perspektiva je pravna i teorijska koja se odnosi na konkretan način na koji je neka država uredila sustav maloljetničkog pravosuđa svojim zakonskim aktima i koliko su ti zakonski akti usklađeni s teorijski utemeljenim načelima uspješnih intervencija prema maloljetnim počiniteljima kaznenih djela. Ona je povezana sa znanstveno-empirijskom perspektivom, s obzirom na to da su današnji priznati teorijski principi utemeljeni na empirijskim provjerama znanstvenih istraživanja o uspješnim intervencijama i sustavima općenito. ${ }^{29}$ Slijedom navedenoga, Murphy i suradnici ${ }^{30}$ navode šest široko postavljenih načela učinkovite suvremene prakse u području maloljetničkog pravosuđa, a to su: (1) utemeljenost politike i sustava na

29 Ricijaš, N. (2017), op. cit. u bilj. 4, str. 123-125.

30 Murphy, P., McGinnes, A., McDermott, T. (2010), Review of Effective Practice in Juvenile Justice, Report for the Minister for Juvenile Justice, Noetic Solutions Pty Limited, Manuka, Australia, objavljeno na: <http://www.juvenile.justice.nsw.gov.au/Documents/Juvenile\%20 Justice\%20Effective\%20Practice\%20Review\%20FINAL.pdf>, zadnji put posjećeno 10 . ožujka 2018. 
znanstveno utemeljenim intervencijama (engl. evidence-based policy formulation), (2) izbjegavanje institucionalizacije maloljetnika kada god je to moguće, (3) pružanje sveobuhvatnih i komplementarnih tretmanskih programa, (4) kreiranje strategija i intervencija prema različitim skupinama korisnika, (5) suradnja svih uključenih sustava te (6) suradnja cijele zajednice. S druge strane, Ricijaš i suradnici, ${ }^{31}$ na temelju paradigme What works, kategoriziraju ključne principe važne za maloljetničko pravosuđe u tri cjeline: 1) principi važni za kazneni postupak i donošenje odluka koji se odnose na važnost određivanja sankcija od državnih autoriteta, na važnost žurnog reagiranja na kazneno djelo koje je počinio maloljetnik, te na važnost primjerene procjene kriminogenog rizika i klasifikacije rizičnosti, 2) principi važni za planiranje intervencija koji se odnose na važnost individualizacije plana intervencije te na njihovu usklađenost s temeljnim potrebama maloljetnika te 3) principi važni za provođenje sankcija koji se usmjeravaju na pojedine postupke voditelja odgojnih mjera/stručnih službi radi što uspješnijeg ishoda za samog maloljetnika.

Osuvremenjivanjem prakse u skladu s međunarodnim i nacionalnim pravnim dokumentima, ali i empirijskim spoznajama o uspješnim intervencijama, osigurat će se maloljetnicima pravo na primjerene intervencije, ${ }^{32}$ što bi uvijek i trebao biti jedan od temeljnih ciljeva. Sukladno tomu, ovaj se rad temelji na jednom dijelu rezultata spomenutog istraživanja, te mu je glavni cilj stjecanje uvida u percepciju stručnjaka o različitim aspektima maloljetničkog pravosuđa koji neposredno rade na provođenju propisanih zakonskih odredbi. Točnije, zanimalo nas je kako stručnjaci zaposleni u centrima za socijalnu skrb, državnim odvjetništvima i sudovima doživljavaju određena načela maloljetničkog pravosuđa, sadržaj zakonskih propisa i kvalitetu izricanja/ izvršavanja maloljetničkih sankcija, te razlikuje li se njihov doživljaj u tom pogledu. Također, na temelju dobivenih rezultata bit će moguće identificirati primjere dobre prakse prema ranije navedenim načelima, ali i izazove u području maloljetničkog pravosuđa.

\section{METODOLOGIJA}

\subsection{Ciljevi istrǎ̌ivanja}

Ciljevi su ovog rada stjecanje uvida u perspektivu stručnjaka o svrsishodnosti sustava maloljetničkog pravosuđa te istraživanje eventualnih razlika u doživljaju različitih aspekata maloljetničkog pravosuđa s obzirom na područja rada. Istraživanje je eksplorativnoga karaktera, te ga nije moguće usporediti sa sličnim istraživanjima na našim prostorima. Stoga je postavljena radna hipoteza da će ispitanici umjereno

31 Ricijaš, N., Jeđud Borić, I., Lotar Rihtarić, M. (2014), Pojačana briga i nadzor iz perspektive mladih i voditelja mjere, UNICEF Ured za Hrvatsku, Zagreb, objavljeno na: <https://www. unicef.hr/wp-content/uploads/2015/09/PBIN_publikacija_web.pdf>, zadnji put posjećeno 1 . ožujka 2018.

32 Ricijaš, N., Pravo maloljetnika na primjeren tretman u izvršavanju alternativnih sankcija, objavljeno u: Vladović, S. (ur.): Zaštita prava i interesa djece s problemima u ponašanju: Zbornik priopćenja sa stručnih skupova pravobraniteljice za djecu, Pravobranitelj za djecu, Zagreb, 2012, str. 245-257. 
pozitivno ocijeniti pojedine aspekte maloljetničkog pravosuđa, te da će najmanji stupanj zadovoljstva biti izražen u onim područjima koja imaju neposredniji utjecaj na svakodnevni rad ispitanika. Tako se očekuje da će zaposlenici državnih odvjetništava $\mathrm{u}$ većoj mjeri biti kritični prema zakonskim propisima koji reguliraju postupanje u kontekstu maloljetničkog pravosuđa, a zaposlenici sustava socijalne skrbi najmanje će biti zadovoljni primijenjenim aspektom u kontekstu izricanja i izvršavanja maloljetničkih sankcija.

\subsection{Sudionici}

Istraživanje je provedeno na uzorku zaposlenika općinskih i županijskih kaznenih sudova, centara za socijalnu skrb te općinskih i županijskih državnih odvjetništava iz svih županija u Hrvatskoj. U istraživanju je sudjelovalo ukupno $\mathrm{n}=473$ sudionika, no konačni uzorak čini $n=309$ sudionika koji su u potpunosti ispunili anketni upitnik.

Tablica 1.: Osnovna obilježja sudionika istraživanja (N=309)

\begin{tabular}{|c|c|c|c|c|c|}
\hline \multicolumn{6}{|c|}{ UKUPAN UZORAK SUDIONIKA (N=309) } \\
\hline INSTITUCIJA ZAPOSLENJA & $\begin{array}{l}\mathbf{N} \\
\%\end{array}$ & ZVANJE & $\begin{array}{l}\mathrm{N} \\
\%\end{array}$ & ZANIMANJE & $\begin{array}{l}\mathrm{N} \\
\%\end{array}$ \\
\hline Centar za socijalnu skrb & $\begin{array}{l}129 \\
41.7\end{array}$ & Pravnik & $\begin{array}{l}141 \\
45.6\end{array}$ & $\begin{array}{l}\text { Stručni suradnik u } \\
\text { centru za socijalnu } \\
\text { skrb }\end{array}$ & $\begin{array}{l}129 \\
41.7\end{array}$ \\
\hline Općinsko državno odvjetništvo & \begin{tabular}{|l|}
67 \\
21.7 \\
\end{tabular} & Socijalni radnik & $\begin{array}{l}72 \\
23.3 \\
\end{array}$ & $\begin{array}{l}\text { Državni odvjetnik } \\
\text { za mladež }\end{array}$ & $\begin{array}{l}72 \\
23.3 \\
\end{array}$ \\
\hline Županijsko državno odvjetništvo & $\begin{array}{l}31 \\
10\end{array}$ & Socijalni pedagog & $\begin{array}{l}69 \\
22.3\end{array}$ & $\begin{array}{l}\text { Savjetnik u } \\
\text { državnom } \\
\text { odvjetništvu }\end{array}$ & $\begin{array}{l}10 \\
3.23\end{array}$ \\
\hline Općinski sud & $\begin{array}{l}54 \\
17.5\end{array}$ & Psiholog & $\begin{array}{l}21 \\
6.8\end{array}$ & $\begin{array}{l}\text { Stručni suradnik } \\
\text { izvanpravne } \\
\text { struke u državnom } \\
\text { odvjetništvu }\end{array}$ & $\begin{array}{l}16 \\
5.18\end{array}$ \\
\hline Županijski sud & $\begin{array}{l}28 \\
9.1\end{array}$ & Ostalo & $\begin{array}{l}6 \\
1.9 \\
\end{array}$ & Sudac za mladež & $\begin{array}{l}57 \\
18.4 \\
\end{array}$ \\
\hline \multirow{2}{*}{\multicolumn{4}{|c|}{$\begin{array}{l}\text { Prosjek godina staža na poslovima delinkvencije mladih } \\
=11.5 \text { godina }(\mathrm{SD}=9.208)\end{array}$}} & Savjetnik na sudu & $\begin{array}{l}6 \\
1.9 \\
\end{array}$ \\
\hline & & & & $\begin{array}{l}\text { Stručni suradnik } \\
\text { izvanpravne struke } \\
\text { na sudu }\end{array}$ & $\begin{array}{l}19 \\
6.15\end{array}$ \\
\hline
\end{tabular}

Prosjek godina staža na poslovima delinkvencije mladih je 11.5 godina ( $\mathrm{SD}=9.208$ ), no treba uzeti u obzir kako je raspon zaista velik ( $\mathrm{SD}=9.21$ ), od onih koji na tim poslovima rade manje od godinu dana, do onih koji na poslovima delinkvencije mladih rade čak 40 godina. 


\subsection{Instrumentarij}

Istraživanje je provedeno online anketnim upitnikom pri čemu su postojale tri paralelne forme upitnika, ovisno o instituciji zaposlenja te tri tematska područja: (1) opći podatci o sudionicima i ustanovi zaposlenja, (2) pitanja o percepciji funkcioniranja maloljetničkog pravosuđa te (3) pitanja o kvaliteti i zadovoljstvu međuresorne suradnje tih triju institucija. Za ostvarivanje ciljeva ovog rada, korištena su prva dva dijela upitnika.

Kroz pitanja o općim podatcima o sudionicima prikupljeni su podatci o instituciji zaposlenja, županiji iz koje dolaze, struci i zanimanju, godinama staža na poslovima maloljetničke delinkvencije te udjelu mjesečnog opterećenja rada na poslovima delinkvencije mladih.

Pitanja o percepciji funkcioniranja maloljetničkog pravosuđa podijeljena su u četiri potkategorije: prva se odnosi na zadovoljstvo načelima maloljetničkog pravosuđa, druga na zadovoljstvo sadržajem zakonskih propisa vezano za intervencije i postupanje prema maloljetnim počiniteljima kaznenih djela, treća na zadovoljstvo kvalitetom izricanja, a četvrta na zadovoljstvo kvalitetom izvršavanja maloljetničkih sankcija.

\subsection{Način prikupljanja podataka}

Podatci su prikupljani putem LimeSurvey platforme na kojoj je postavljen upitnik, a poveznice na upitnike distribuirane su putem nadležnih ministarstava (zaposlenicima centara za socijalnu skrb, sucima za mladež te stručnim suradnicima izvanpravne struke na sudovima) i ureda Glavnog državnog odvjetnika Republike Hrvatske (svim zamjenicima državnih odvjetnika i stručnim suradnicima izvanpravne struke u državnim odvjetništvima), tijekom studenog i prosinca 2015. godine. Ispunjavanje upitnika bilo je u potpunosti anonimno.

\subsection{Metode obrade podataka}

Uz deskriptivnu statistiku (mjere centralnih vrijednosti i frekvencije odgovora), korišten je Kruskal-Wallisov test kao neparametrijska metoda obrade podataka, budući da je Kolmogorov-Smirnov i Shapiro-Wilkov test pokazao značajno odstupanje rezultata od normalne distribucije. Mann-Whitneyev test korišten je kao post hoc test, uz testiranje veličine efekta razlika formulom $\mathrm{r}=\mathrm{Z} / \sqrt{\mathrm{N}}$. Uz kvantitativnu, korištena je i kvalitativna analiza radi dobivanja detaljnijeg obrazloženja pojedinih kvantitativnih odgovora.

\section{REZULTATI I RASPRAVA}

Kao što je ranije navedeno, cilj je ovog istraživanja bio ispitati doživljaj maloljetničkog pravosuđa iz perspektive ključnih institucija koje čine okosnicu kaznenog postupanja prema maloljetnicima, a to su centri za socijalnu skrb, državna 
odvjetništva te sudovi za mladež. Ispitivalo se zadovoljstvo načelima maloljetničkog pravosuđa, zadovoljstvo sadržajem zakonskih propisa te zadovoljstvo kvalitetom izricanja i izvršavanja maloljetničkih sankcija.

Zadovoljstvo funkcioniranjem sustava u kontekstu načela maloljetničkog pravosuđa istraženo je na način da su sudionici za svako ponuđeno načelo na ljestvici od pet stupnjeva izražavali stupanj svojeg zadovoljstva primjenom tog načela, pri čemu su svoj kvantitativni odgovor mogli obrazložiti i kvalitativno, kako bi se dobio detaljniji uvid u odgovore sudionika.

Tablica 2.: Deskriptivni prikaz zadovoljstva načelima maloljetničkog pravosuđa $(\mathrm{N}=309)$ i razlike u zadovoljstvu načelima s obzirom na ustanovu zaposlenja (KruskalWallisov test i Mann-Whitneyev test kao post hoc test, uz efekt razlike)

\begin{tabular}{|c|c|c|c|c|c|c|c|c|c|c|c|c|c|}
\hline \multirow{2}{*}{ NAČELO } & \multirow{2}{*}{ USTANOVA } & \multirow{2}{*}{$N$} & \multicolumn{5}{|c|}{$\%$} & \multirow{2}{*}{$M$} & \multirow{2}{*}{$S D$} & \multirow{2}{*}{$P R$} & \multirow{2}{*}{$\boldsymbol{K} \boldsymbol{W}$} & \multirow{2}{*}{$M W U$} & \multirow{2}{*}{$r$} \\
\hline & & & 1 & 2 & 3 & 4 & 5 & & & & & & \\
\hline \multirow{3}{*}{ Hitnost } & CZSS & 129 & 3.1 & 16.3 & 24.8 & 50.4 & 5.4 & 3.39 & .930 & 162.21 & \multirow{3}{*}{$13.013 * *$} & \multirow{3}{*}{$\begin{array}{l}\mathrm{DO}<\mathrm{CZSS}^{* *} \\
\mathrm{DO}<\text { SUD }^{* *}\end{array}$} & \multirow{3}{*}{$\begin{array}{l}0.18 \\
0.24\end{array}$} \\
\hline & DO & 98 & 8.2 & 23.5 & 28.6 & 38.8 & 1.0 & 3.01 & 1.00 & 130.70 & & & \\
\hline & SUD & 82 & 2.4 & 14.6 & 20.7 & 54.9 & 7.3 & 3.50 & .920 & 172.69 & & & \\
\hline \multirow{3}{*}{ Pravovremenost } & CZSS & 129 & 3.9 & 16.3 & 32.6 & 41.1 & 6.2 & 3.29 & .947 & 158.21 & \multirow{3}{*}{$17.388^{* * * *}$} & \multirow{3}{*}{$\begin{array}{l}\mathrm{DO}<\mathrm{CZSS}^{* *} \\
\mathrm{DO}<\mathrm{SUD}^{* * *}\end{array}$} & \multirow{3}{*}{$\begin{array}{l}0.17 \\
0.30\end{array}$} \\
\hline & DO & 98 & 2.0 & 30.6 & 34.7 & 31.6 & 1.0 & 2.99 & .867 & 128.96 & & & \\
\hline & SUD & 82 & 3.7 & 9.8 & 24.4 & 54.9 & 7.3 & 3.52 & .906 & 181.08 & & & \\
\hline \multirow{3}{*}{ Postupnost } & CZSS & 129 & 0.8 & 0.8 & 31.8 & 58.9 & 7.8 & 3.72 & .649 & 152.50 & \multirow{3}{*}{$9.021 *$} & \multirow{3}{*}{$\begin{array}{l}\mathrm{CZSS}<\mathrm{SUD}^{*} \\
\mathrm{DO}<\mathrm{SUD}^{* *}\end{array}$} & \multirow{3}{*}{$\begin{array}{l}0.14 \\
0.21\end{array}$} \\
\hline & DO & 98 & 1.0 & 10.2 & 28.6 & 51.0 & 9.2 & 3.57 & .837 & 140.79 & & & \\
\hline & SUD & 82 & 0.0 & 2.4 & 18.3 & 64.6 & 14.6 & 3.91 & .652 & 175.92 & & & \\
\hline \multirow{3}{*}{ Promjenjivost } & CZSS & 129 & 1.6 & 10.9 & 27.9 & 48.8 & 10.9 & 3.57 & .883 & 159.93 & \multirow{3}{*}{5.326} & \multirow{3}{*}{-} & \multirow{3}{*}{-} \\
\hline & DO & 98 & 3.1 & 11.2 & 39.8 & 37.8 & 8.2 & 3.37 & .901 & 139.41 & & & \\
\hline & SUD & 82 & 0.0 & 9.8 & 25.6 & 56.1 & 8.5 & 3.63 & .778 & 165.88 & & & \\
\hline
\end{tabular}

Legenda: N=uzorak sudionika; 1=uopće nisam zadovoljan; 2=uglavnom nisam zadovoljan; 3=niti zadovoljan, niti nezadovoljan; 4=uglavnom sam zadovoljan; $5=\mathrm{u}$ potpunosti sam zadovoljan; $\mathrm{M}=$ aritmetička sredina; $\mathrm{SD}=$ standardna devijacija; $\mathrm{KW}$ $\chi^{2}=$ Kruskal-Wallis Hi-kvadrat; MWU=Mann-Whitney U-test; $\mathrm{r}=$ veličina efekta; ${ }^{*} \mathrm{p}<.050 ; * * \mathrm{p}<.010 ; * * * \mathrm{p}<.001$

Analizom odgovora sudionika utvrđeno je kako prosječne vrijednosti odgovora na svim ispitivanim varijablama i unutar svih ustanova ukazuju na to da su stručnjaci umjereno zadovoljni primjenom svih načela (prosječne vrijednosti kreću se od 2.99 do 3.91). istodobno je vidljivo da su zaposlenici državnog odvjetništva najmanje zadovoljni svim načelima osim načelom promjenjivosti sankcije ( $\mathrm{KW}=5.326 ; \mathrm{p}>.05)$. Točnije, iz prosječnih je vrijednosti odgovora, koje se kreću od srednjih prema višim, vidljivo kako su stručnjaci svih triju institucija uglavnom zadovoljni primjenom ovog načela. Takve rezultate potvrđuju i kvalitativni odgovori sudionika u kojima navode kako se ovog načela u pravilu svi pridržavaju i kako postoji kvalitetna komunikacija između institucija vezano uz promjenu sankcije maloljetniku ako se za to ukaže 
potreba.

Kada je riječ o načelu hitnosti, utvrđene su značajne razlike u percepciji između zaposlenika centara za socijalnu skrb, sudova i državnih odvjetništava $(\mathrm{KW}=13.013 ; \mathrm{p}<.01)$, a rezultati post hoc testa pokazuju kako razlike postoje između državnih odvjetništava i centara za socijalnu skrb, te između državnih odvjetništava i sudova na način da su zaposlenici državnih odvjetništava u odnosu na zaposlenike centara za socijalnu skrb manje zadovoljni primjenom načela hitnosti, pri čemu su efekti tih razlika relativno mali (MWU=5024.0; $\mathrm{r}=0.18)$. U slučaju razlika između državnih odvjetništava i sudova, efekt razlika je nešto veći (MWU=2934.0; r=0.24) te se kreće prema srednjim vrijednostima. Rezultati su slični i kada je riječ o načelu pravovremenosti (KW=17.388; $\mathrm{p}<.001)$ i kreću se $\mathrm{u}$ istom smjeru, kao i kod načela hitnosti. Razlike postoje između državnih odvjetništava i centara za socijalnu skrb te između državnih odvjetništava i sudova na način da su zaposlenici državnih odvjetništava manje zadovoljni primjenom načela pravovremenosti u odnosu na zaposlenike drugih dviju institucija.

Kod načela postupnosti, razlike u percepciji postoje između zaposlenika centara za socijalnu skrb i sudova (MWU=4456.5; $\mathrm{p}<.05)$ te između zaposlenika državnih odvjetništava i sudova (MWU=3135.0; p<.01). Kao što je to bilo i prethodno slučaj, zaposlenici državnih odvjetništava su manje zadovoljni primjenom načela postupnosti u odnosu na druge dvije institucije pri čemu su efekti tih razlika ponovno relativno niski.

Kako bi se stekao bolji uvid u pozadinu tih razlika, analiziran je kvalitativni dio odgovora koji ukazuje da stručnjaci iz državnih odvjetništava izvještavaju o svojevrsnom ,zastoju“ kada je riječ o primjeni načela hitnosti i pravovremenosti zbog dugotrajnih postupaka na sudovima (presporo reagiranje sudaca, protok vremena prije zakazivanja ročišta, nedovoljna brzina postupanja sudova nakon podnesenih prijedloga državnog odvjetništva). Kada je riječ o primjeni načela postupnosti i promjenjivosti sankcije, stručnjaci iz državnih odvjetništava iskazuju nešto veće zadovoljstvo i navode kako se svakom pojedinom slučaju pristupa individualno te da se u pravilu gotovo uvijek primjenjuju oba načela. S druge strane, rezultati pokazuju kako su zaposlenici na općinskim i županijskim sudovima najzadovoljniji primjenom svih načela maloljetničkog pravosuđa. Kao glavne razloge svog zadovoljstva navode kako se maloljetnički predmeti uvijek uzimaju žurno u postupak, kako se poštuju zakonom predviđeni rokovi, te navode kako se iznimno cijeni angažman državnih odvjetnika vezano za načelo pravovremenosti sankcije (posebno vezano za uvjetovani oportunitet).

Istraživanjem se ispitalo i zadovoljstvo sadržajem zakonskih propisa vezanih za primjenu načela (uvjetovanog) oportuniteta, izbora odgojnih mjera te izricanje kazne maloljetničkog zatvora i sigurnosnih mjera, a rezultati su prikazani u Tablici 3. 
Tablica 3.: Deskriptivni prikaz zadovoljstva sadržajem zakonskih propisa $(\mathrm{N}=309)$ i razlike u zadovoljstvu zakonskim propisima s obzirom na ustanovu zaposlenja (Kruskal-Wallisov test i Mann-Whitneyev test kao post hoc test, uz efekt razlike)

\begin{tabular}{|c|c|c|c|c|c|c|c|c|c|c|c|c|c|}
\hline \multirow{2}{*}{$\begin{array}{c}\text { SADRŽAJ } \\
\text { ZAKONSKIH } \\
\text { PROPISA }\end{array}$} & \multirow[b]{2}{*}{ USTANOVA } & \multirow[b]{2}{*}{$N$} & \multicolumn{5}{|c|}{$\%$} & \multirow[b]{2}{*}{$M$} & \multirow[b]{2}{*}{$S D$} & \multirow[b]{2}{*}{$P R$} & \multirow[b]{2}{*}{$K \boldsymbol{W}$} & \multirow[b]{2}{*}{$M W U$} & \multirow[b]{2}{*}{$r$} \\
\hline & & & 1 & 2 & 3 & 4 & 5 & & & & & & \\
\hline \multirow{3}{*}{$\begin{array}{l}\text { Primjena načela } \\
\text { oportuniteta i } \\
\text { uvjetovanog } \\
\text { oportuniteta }\end{array}$} & CZSS & 129 & 2.3 & 1.6 & 20.2 & 56.6 & 19.4 & 3.89 & .812 & 154.81 & \multirow{3}{*}{$16.036^{* * *}$} & \multirow{3}{*}{$\begin{array}{l}\mathrm{DO}<\mathrm{CZSS} * \\
\mathrm{CZSS}<\mathrm{SUD}^{*} \\
\mathrm{DO}<\mathrm{SUD}^{* * *}\end{array}$} & \multirow{3}{*}{$\begin{array}{l}0.13 \\
0.16 \\
0.29\end{array}$} \\
\hline & DO & 98 & 1.0 & 2.0 & 32.7 & 52.0 & 12.3 & 3.72 & .743 & 133.14 & & & \\
\hline & SUD & 82 & 0.0 & 4.9 & 7.3 & 57.3 & 30.5 & 4.13 & .750 & 181.43 & & & \\
\hline \multirow{3}{*}{$\begin{array}{l}\text { Izbor odgojnih } \\
\text { mjera u } \\
\text { zajednici }\end{array}$} & CZSS & 129 & 0.0 & 5.4 & 14.0 & 64.3 & 16.3 & 3.91 & .718 & 160.59 & \multirow{3}{*}{$8.029^{*}$} & \multirow{3}{*}{$\begin{array}{l}\text { DO }<\text { CZSS }^{*} \\
\text { DO }<\text { SUD** }\end{array}$} & \multirow{3}{*}{$\begin{array}{l}0.15 \\
0.19\end{array}$} \\
\hline & DO & 98 & 1.0 & 13.3 & 18.4 & 55.1 & 12.2 & 3.64 & .900 & 136.95 & & & \\
\hline & SUD & 82 & 0.0 & 3.7 & 14.6 & 61.0 & 20.7 & 3.99 & .711 & 167.77 & & & \\
\hline \multirow{3}{*}{$\begin{array}{l}\text { Izbor } \\
\text { institucionalnih } \\
\text { odgojnih mjera }\end{array}$} & CZSS & 129 & 0.0 & 14.0 & 24.0 & 55.0 & 7.0 & 3.55 & .819 & 161.45 & \multirow{3}{*}{5.777} & & \multirow{3}{*}{ - } \\
\hline & DO & 98 & 2.0 & 20.4 & 28.6 & 43.9 & 5.1 & 3.30 & .922 & 138.45 & & & \\
\hline & SUD & 82 & 0.0 & 11.0 & 31.7 & 42.7 & 14.6 & 3.61 & .871 & 164.62 & & & \\
\hline \multirow{3}{*}{$\begin{array}{l}\text { Izricanje } \\
\text { maloljetničkog } \\
\text { zatvora }\end{array}$} & CZSS & 129 & 0.8 & 5.4 & 28.7 & 53.5 & 11.6 & 3.70 & .777 & 153.02 & \multirow{3}{*}{$11.634 * *$} & \multirow{3}{*}{$\begin{array}{l}\text { CZSS }<\text { SUD* } \\
\text { DO }<\text { SUD }^{* *}\end{array}$} & \multirow{3}{*}{$\begin{array}{l}0.15 \\
0.24\end{array}$} \\
\hline & DO & 98 & 1.0 & 6.1 & 37.8 & 45.9 & 9.2 & 3.56 & .787 & 137.57 & & & \\
\hline & SUD & 82 & 1.2 & 3.7 & 17.1 & 57.3 & 20.7 & 3.93 & .798 & 178.96 & & & \\
\hline \multirow{3}{*}{$\begin{array}{l}\text { Izricanje } \\
\text { sigurnosnih } \\
\text { mjera }\end{array}$} & CZSS & 129 & 2.3 & 10.9 & 27.9 & 51.2 & 7.8 & 3.51 & .876 & 155.65 & \multirow{3}{*}{$27.693 * * *$} & \multirow{3}{*}{$\begin{array}{l}\mathrm{DO}<\mathrm{CZSS}^{* *} \\
\mathrm{CZSS}<\mathrm{SUD}^{* *} \\
\mathrm{DO}<\mathrm{SUD}^{* * *}\end{array}$} & \multirow{3}{*}{$\begin{array}{l}0.18 \\
0.20 \\
0.38\end{array}$} \\
\hline & DO & 98 & 4.1 & 16.3 & 38.8 & 37.8 & 3.1 & 3.19 & .893 & 124.82 & & & \\
\hline & SUD & 82 & 0.0 & 3.7 & 22.0 & 56.0 & 18.3 & 3.89 & .737 & 190.04 & & & \\
\hline
\end{tabular}

Legenda: N=uzorak sudionika; 1=uopće nisam zadovoljan; 2=uglavnom nisam zadovoljan; $3=$ niti zadovoljan, niti nezadovoljan; 4=uglavnom sam zadovoljan; $5=\mathrm{u}$ potpunosti sam zadovoljan; $\mathrm{M}=$ aritmetička sredina; $\mathrm{SD}=$ standardna devijacija; $\mathrm{KW}$ $\chi^{2}=$ Kruskal-Wallis Hi-kvadrat; MWU=Mann-Whitney U-test; $\mathrm{r}=$ veličina efekta; $* \mathrm{p}<.050 ; * * \mathrm{p}<.010 ; * * * \mathrm{p}<.001$

Iz Tablice 3. vidljivo je kako na gotovo svim ispitivanim područjima postoji značajna razlika u zadovoljstvu sadržajem zakonskih propisa, s iznimkom zadovoljstva sadržajem zakonskih propisa vezano za izbor institucionalnih odgojnih mjera $(\mathrm{KW}=5.777 ; \mathrm{p}>.05)$, gdje su prosječne vrijednosti odgovora približne i kreću se oko srednjih vrijednosti. Uvidom u kvalitativni dio odgovora na toj varijabli, uočava se da su sudionici (neovisno o instituciji zaposlenja) suglasni oko problema nedovoljnih smještajnih kapaciteta te nedovoljne diferencijacije tretmana što su, pak, izazovi koji opterećuju izvršavanje ove skupine maloljetničkih sankcija, ali se vidljivo odražavaju u generalnom nezadovoljstvu sudionika povezanog s tim odgojnim mjerama.

Kada se govori o zadovoljstvu sadržajem zakonskih propisa vezano za primjenu načela oportuniteta $i$ uvjetovanog oportuniteta, prosječne vrijednosti odgovora zaposlenika svih triju institucija relativno su visoke (od 3.72 do čak 4.13), što govori $\mathrm{u}$ prilog relativnom zadovoljstvu primjenom ovih načela. No, ipak postoje razlike između svih triju institucija $(\mathrm{KW}=16.036$; $\mathrm{p}<.001)$. I ovdje su zaposlenici državnih odvjetništava u manjoj mjeri zadovoljni sadržajem zakonskih propisa vezanih za oportunitet i uvjetovani oportunitet, no s niskim, odnosno srednjim efektom tih razlika. Uvidom u kvalitativni dio odgovora uočava se kako su svi sudionici zadovoljni sadržajem zakonskih propisa vezanih za oportunitet, naglašavajući kako je „osvježenje“ u pravosudnom sustavu, pogotovo uvođenjem izvansudske nagodbe te kako ubrzava mogućnost utjecanja na maloljetnog počinitelja kaznenog djela, 
ali i pruža mogućnost niskorizičnim maloljetnicima da izbjegnu sudski postupak i istodobno snose odgovornost za počinjeno djelo. Područje koje stručnjaci iz državnih odvjetništava naglašavaju kao ,prostor za napredak“ povećanje je opsega primjene (uvjetovanog) oportuniteta i na kaznena djela za koja je zapriječena kazna veća od pet godina, što posljedično utječe i na njihov kritičniji stav prema ovom području.

Promatrajući prosječne vrijednosti, primjetno je kako su stručnjaci svih triju institucija uglavnom zadovoljni zakonskim propisima vezanim za izbor odgojnih mjera u zajednici (kreću se od 3.64 do 3.99), no i ovdje je subuzorak stručnjaka iz državnih odvjetništava u manjoj mjeri zadovoljan. Oni u svojim komentarima kao uzroke manjeg zadovoljstva navode nepostojanje podzakonskih uputa o primjeni odgojnih mjera u zajednici, te nemogućnost provedbe nekih posebnih obveza zbog nedostatnih resursa zajednice, što realno predstavlja izazov u društvu. S druge strane, kao važne čimbenike koji utječu na zadovoljstvo zakonskim propisima oko izbora odgojnih mjera u zajednici, stručnjaci iz svih triju institucija navode široku paletu posebnih obveza koje zakon predviđa te kvalitetu odgojne mjere pojačane brige i nadzora. No, ono što također navode je vrlo dobra zakonska osnova za primjenu izvaninstitucionalnih odgojnih mjera, međutim kada se radi o njihovoj konkretnoj provedbi u praksi, postoji mnogo segmenata koje bi trebalo unaprijediti, a kao primjere navode definiranje mentora pri izvršavanju humanitarnog rada te redovite supervizije za voditelje PBIN-a.

Slična je situacija i kod zadovoljstva propisima vezanim za izricanje maloljetničkog zatvora i sigurnosnih mjera, gdje su svi sudionici uglavnom zadovoljni, dok su državna odvjetništva najmanje zadovoljna zakonskim propisima. Kvalitativni odgovori naglašavaju kako zakon dobro uređuje izricanje maloljetničkog zatvora, ali ono što ih brine je izvršavanje ove sankcije, odnosno nemaju praksu izricati ga zbog niskih standarda izvršavanja. Stručnjaci iz državnih odvjetništava najviše naglašavaju nezadovoljstvo standardima izvršavanja maloljetničkog zatvora. Kao glavne zamjerke zakonskim propisima povezanim s izricanjem sigurnosnih mjera, sudionici iz svih triju institucija naglašavaju kako „zakon ne prati praksu“, što posljedično rezultira nekvalitetnim izvršavanjem sigurnosnih mjera te kako zakon nedovoljno definira način kontrole provedbe. Oni sudionici koji su zadovoljni, ističu kako su sigurnosne mjere zakonski dobro definirane, ali da u praksi rijetko kada imaju slučajeve u kojima su izrečene, pa nemaju dovoljno iskustva s njima.

Iz prikazanih rezultata možemo zaključiti generalno u prilog relativnom zadovoljstvu sudionika sadržajem zakonskih propisa, dok su stručnjaci iz državnih odvjetništava najkritičniji prema sustavu, što se posljedično odražava i u njihovom generalnom zadovoljstvu. Kvalitativni odgovori ukazuju zapravo na nezadovoljstvo samom primjenom i izvršavanjem pojedinih odgojnih mjera.

Treće ispitivano područje odnosi se na zadovoljstvo kvalitetom izricanja maloljetničkih sankcija s praktične, odnosno primjenjive razine. Sudionici su odgovarali na ljestvici od pet stupnjeva (od potpunog nezadovoljstva do potpunog zadovoljstva), a oni sudionici koji nisu imali iskustva $\mathrm{s}$ ispitivanim područjima mogli su označiti odgovor „ne mogu procijeniti“. Kao i u prethodnim dijelovima instrumentarija, ponuđena je mogućnost obrazloženja svakoga pojedinog odgovora, 
čime su omogućeni kvalitativni podatci radi produbljivanja argumentacije.

Tablica 4.: Deskriptivni prikaz zadovoljstva kvalitetom izricanja maloljetničkih sankcija $(\mathrm{N}=309)$ i razlike u zadovoljstvu kvalitetom izricanja maloljetničkih sankcija s obzirom na ustanovu zaposlenja (Kruskal-Wallisov test i Mann-Whitneyev test kao post hoc test, uz efekt razlike)

\begin{tabular}{|c|c|c|c|c|c|c|c|c|c|c|c|c|c|c|}
\hline \multirow{2}{*}{$\begin{array}{l}\text { KVALITETA } \\
\text { IZRICANJA }\end{array}$} & \multirow{2}{*}{ USTANOVA } & \multirow{2}{*}{$N$} & \multicolumn{5}{|c|}{$\%$} & \multirow[b]{2}{*}{5} & \multirow{2}{*}{$M$} & \multirow{2}{*}{$S D$} & \multirow{2}{*}{$P R$} & \multirow{2}{*}{$K \boldsymbol{W}$} & \multirow{2}{*}{$M W U$} & \multirow{2}{*}{$R$} \\
\hline & & & 0 & 1 & 2 & 3 & 4 & & & & & & & \\
\hline \multirow{3}{*}{$\begin{array}{l}\text { Posebnih } \\
\text { obveza }\end{array}$} & CZSS & 129 & 7.0 & 2.3 & 8.5 & 20.2 & 53.5 & 8.5 & 3.36 & 1.250 & 146.96 & \multirow{3}{*}{4.415} & \multirow{3}{*}{ - } & \multirow{3}{*}{ - } \\
\hline & DO & 98 & 0.0 & 1.0 & 14.3 & 20.4 & 56.1 & 8.2 & 3.56 & .874 & 152.39 & & & \\
\hline & SUD & 82 & 1.2 & 1.2 & 7.3 & 20.7 & 51.2 & 18.3 & 3.74 & .966 & 170.77 & & & \\
\hline \multirow{3}{*}{$\begin{array}{l}\text { Upućivanja u } \\
\text { disciplinski } \\
\text { centar }\end{array}$} & CZSS & 129 & 15.5 & 3.9 & 9.3 & 30.2 & 32.6 & 8.5 & 2.86 & 1.519 & 161.72 & \multirow{3}{*}{2.214} & \multirow{3}{*}{ - } & \multirow{3}{*}{ - } \\
\hline & DO & 98 & 12.2 & 9.2 & 15.3 & 32.7 & 25.5 & 5.1 & 2.65 & 1.408 & 144.67 & & & \\
\hline & SUD & 82 & 12.2 & 2.4 & 17.1 & 30.5 & 32.9 & 4.9 & 2.84 & 1.374 & 156.77 & & & \\
\hline \multirow{3}{*}{$\begin{array}{l}\text { PBIN kada je } \\
\text { provodi Centar }\end{array}$} & CZSS & 129 & 7.8 & 1.6 & 10.9 & 22.5 & 39.5 & 17.8 & 3.38 & 1.359 & 149.11 & \multirow{3}{*}{5.684} & \multirow{3}{*}{ - } & \multirow{3}{*}{ - } \\
\hline & DO & 98 & 4.1 & 1.0 & 4.1 & 15.3 & 61.2 & 14.3 & 3.71 & 1.065 & 171.42 & & & \\
\hline & SUD & 82 & 4.9 & 0.0 & 9.8 & 29.3 & 45.1 & 11.0 & 3.43 & 1.123 & 144.63 & & & \\
\hline \multirow{3}{*}{$\begin{array}{l}\text { PBIN kada } \\
\text { je provode } \\
\text { vanjski } \\
\text { suradnici }\end{array}$} & CZSS & 129 & 9.3 & 0.8 & 7.0 & 26.4 & 45.7 & 10.9 & 3.31 & 1.322 & 150.74 & \multirow{3}{*}{$6.231 *$} & \multirow{3}{*}{$\mathrm{SUD}<\mathrm{DO}^{*}$} & \\
\hline & DO & 98 & 5.1 & 1.0 & 4.1 & 19.4 & 59.2 & 11.2 & 3.60 & 1.110 & 171.50 & & & 0.18 \\
\hline & SUD & 82 & 9.8 & 1.2 & 3.7 & 35.4 & 41.5 & 8.5 & 3.23 & 1.299 & 141.98 & & & \\
\hline PBIN uz & CZSS & 129 & 27.1 & 3.9 & 5.4 & 33.3 & 22.5 & 7.8 & 2.43 & 1.699 & 156.09 & & & \\
\hline boravak u & DO & 98 & 29.6 & 7.1 & 9.2 & 25.5 & 23.5 & 5.1 & 2.21 & 1.701 & 145.71 & 2.119 & - & - \\
\hline ustanovi & SUD & 82 & 24.4 & 0.0 & 9.8 & 28.0 & 34.1 & 3.7 & 2.59 & 1.625 & 164.38 & & & \\
\hline & CZSS & 129 & 9.3 & 6.2 & 12.4 & 28.7 & 38.0 & 5.4 & 2.96 & 1.349 & 142.62 & & & \\
\hline u odgojnu & DO & 98 & 3.1 & 6.1 & 8.2 & 37.8 & 38.8 & 6.1 & 3.21 & 1.096 & 154.04 & $7.678^{*}$ & $\mathrm{CZSS}<\mathrm{SUD}^{* *}$ & 0.18 \\
\hline & SUD & 82 & 2.4 & 2.4 & 6.1 & 30.5 & 51.2 & 7.3 & 3.48 & .984 & 175.62 & & & \\
\hline Upućivanja & CZSS & 129 & 19.4 & 3.9 & 10.1 & 31.8 & 31.0 & 3.9 & 2.63 & 1.531 & 149.84 & & & \\
\hline u posebnu & DO & 98 & 14.3 & 4.1 & 7.1 & 39.8 & 30.6 & 4.1 & 2.81 & 1.404 & 157.72 & .829 & - & - \\
\hline ustanovu & SUD & 82 & 12.2 & 8.5 & 7.3 & 35.4 & 29.3 & 7.3 & 2.83 & 1.447 & 159.87 & & & \\
\hline & CZSS & 129 & 11.6 & 7.8 & 9.3 & 29.5 & 31.8 & 10.1 & 2.92 & 1.477 & 147.79 & & & \\
\hline $\begin{array}{l}\text { Upucivanja u } \\
\text { dooini zavod }\end{array}$ & DO & 98 & 13.3 & 3.1 & 5.1 & 32.7 & 36.7 & 9.2 & 3.04 & 1.457 & 156.01 & 2.083 & - & - \\
\hline & SUD & 82 & 6.1 & 2.4 & 7.3 & 32.9 & 46.3 & 4.9 & 3.26 & 1.153 & 165.13 & & & \\
\hline & CZSS & 129 & 27.1 & 3.9 & 7.0 & 28.7 & 24.8 & 8.5 & 2.46 & 1.728 & 146.15 & & & \\
\hline maloljetničkog & DO & 98 & 20.4 & 0.0 & 7.1 & 37.8 & 29.6 & 5.1 & 2.71 & 1.533 & 156.05 & 3.157 & - & - \\
\hline & SUD & 82 & 14.6 & 2.4 & 7.3 & 34.1 & 35.4 & 6.1 & 2.91 & 1.450 & 167.68 & & & \\
\hline Pridržaja & CZSS & 129 & 12.4 & 0.8 & 7.8 & 27.9 & 41.1 & 10.1 & 3.15 & 1.426 & 155.17 & & $\mathrm{DO}$ & 012 \\
\hline $\begin{array}{l}\text { Kazne } \\
\text { maloljetničkog }\end{array}$ & DO & 98 & 15.3 & 1.0 & 13.3 & 29.6 & 37.8 & 3.1 & 2.83 & 1.429 & 132.46 & $15.127 * *$ & CZSS $<$ SUD $^{*}$ & 0.15 \\
\hline zatvora & SUD & 82 & 4.9 & 0.0 & 7.3 & 20.7 & 54.9 & 12.2 & 3.57 & 1.111 & 181.66 & & $S U D^{*}$ & 0.29 \\
\hline
\end{tabular}




\begin{tabular}{|c|c|c|c|c|c|c|c|c|c|c|c|c|c|c|}
\hline \multirow{3}{*}{$\begin{array}{l}\text { Sigurnosnih } \\
\text { mjera }\end{array}$} & CZSS & 129 & 20.9 & 3.9 & 5.4 & 41.1 & 23.3 & 5.4 & 2.58 & 1.545 & 154.46 & \multirow{3}{*}{$6.396 *$} & \multirow{3}{*}{$\mathrm{DO}<\mathrm{SUD}^{* *}$} & \multirow{3}{*}{0.18} \\
\hline & DO & 98 & 19.4 & 6.1 & 14.3 & 36.7 & 23.5 & 0.0 & 2.39 & 1.419 & 140.59 & & & \\
\hline & SUD & 82 & 20.7 & 0.0 & 7.3 & 28.0 & 35.4 & 8.5 & 2.83 & 1.624 & 173.08 & & & \\
\hline
\end{tabular}

Legenda: $\mathrm{N}=$ uzorak sudionika; $0=$ ne mogu procijeniti; $1=$ uopće nisam zadovoljan; 2=uglavnom nisam zadovoljan; $3=$ niti zadovoljan, niti nezadovoljan; 4=uglavnom sam zadovoljan; 5=u potpunosti sam zadovoljan; $\mathrm{M}=$ aritmetička sredina; $\mathrm{SD}=$ standardna devijacija; KW $\chi^{2}=$ Kruskal-Wallis Hi-kvadrat; MWU=Mann-Whitney U-test; $\mathrm{r}=$ veličina efekta; $* \mathrm{p}<.050 ; * * \mathrm{p}<.010 ; * * * \mathrm{p}<.001$

Iz Tablice 4. uočava se da kada je riječ o percepciji stručnjaka vezano za kvalitetu izricanja posebnih obveza, upućivanja u disciplinski centar, PBIN kada je provodi Centar, PBIN uz dnevni boravak u odgojnoj ustanovi, upućivanje u posebnu odgojnu ustanovu, upućivanje u odgojni zavod te kazne maloljetničkog zatvora ne postoji statistički značajna razlika. Primjerice, zaposlenici svih triju institucija u velikoj su mjeri zadovoljni odgojnom mjerom posebne obveze, a na temelju njihovih odgovora zaključuje se da je glavni razlog zadovoljstva široki spektar posebnih obveza. Sličan trend je i kod izricanja PBIN-a kada je provodi centar za socijalnu skrb gdje su sudionici svih triju institucija uglavnom zadovoljni, ali stručnjaci iz centara za socijalnu skrb kao glavne razloge manjeg zadovoljstva navode prekapacitiranost ostalim poslovima koje moraju obavljati, zbog čega im u tretmanskom aspektu nedostaje vremena kvalitetno se posvetiti radu s maloljetnikom.

S druge strane, svi su stručnjaci podjednako (ne)zadovoljni (prosječne vrijednosti njihovih odgovora kreću se od 2.65 do 2.86) kvalitetom izricanja upućivanja $u$ disciplinski centar, te isto navode kako se ta mjera rijetko ili gotovo nikad ne izriče te kako se predugo čeka na smještaj čime se gubi njezin smisao. Prosječne vrijednosti odgovora kada je riječ o izricanju PBIN-a uz dnevni boravak u odgojnoj ustanovi također ukazuju na trend manjeg zadovoljstva tom odgojnom mjerom. Kao razloge navode nedostatak uvjeta za izricanje ove sankcije u mnogim sredinama te posljedično njezino rijetko izricanje. Kada je riječ o zadovoljstvu izricanja upućivanja u posebnu odgojnu ustanovu, također je primjetno kako su zaposlenici svih triju institucija u manjoj mjeri zadovoljni, što potkrepljuju odgovorima kako je Centar za odgoj i obrazovanje Lug jedina takva ustanova u Hrvatskoj, što je po mnogim sudionicima veliki nedostatak. Svi su sudionici na pitanje o zadovoljstvu kvalitetom izricanja upućivanja u odgojni zavod, kao nedostatak navodili preveliku sličnost s izvršavanjem kazne maloljetničkog zatvora, posebice kada je riječ o diferencijaciji tretmana između tih dviju sankcija. Posljednje područje u kojem ne postoji značajna razlika u percepciji jest zadovoljstvo kvalitetom izricanja kazne maloljetničkog zatvora. Sudionici svih triju institucija su u manjoj mjeri zadovoljni, a kvalitativni dio odgovora govori kako velik broj ispitanika u svojoj profesionalnoj karijeri nije nikada ni imao takav slučaj, dok oni koji su imali, govore o lošim uvjetima izdržavanja kazne (neodgovarajući prostor i sadržaji).

Značajne razlike u percepciji zaposlenika vezano za izricanje sankcija postoje na četiri ispitivana područja, a to su PBIN kada je provode vanjski suradnici, upućivanje u odgojnu ustanovu, pridržaj kazne maloljetničkog zatvora te izricanje sigurnosnih 
mjera. Kada je riječ o zadovoljstvu ispitanika kvalitetom izricanja PBIN-a kada je provode vanjski suradnici, svi su stručnjaci umjereno zadovoljni njezinim izricanjem. Pritom značajna razlika postoji između zaposlenika sudova koji su u manjoj mjeri zadovoljni u odnosu na zaposlenike državnih odvjetništava. No, u kvalitativnom dijelu odgovora, zaposlenici i sudova i državnih odvjetništava naglašavaju kako su zadovoljniji ishodom PBIN-a kada je provode vanjski suradnici jer su motiviraniji i manje opterećeni, no ne mogu procijeniti kvalitetu izricanja s obzirom na to da se izriče odgojna mjera PBIN, a hoće li ju provoditi stručni radnik u centru za socijalnu skrb ili vanjski suradnik, ne ovisi o sucu.

Vezano za upućivanje u odgojnu ustanovu, trend prosječnih vrijednosti također ukazuje na umjereno zadovoljstvo stručnjaka, s time da su zaposlenici centara za socijalnu skrb manje zadovoljni izricanjem ove sankcije u odnosu na zaposlenike sudova. Zaposlenici centara za socijalnu skrb kao glavne razloge svog nezadovoljstva navode predugo čekanje na smještaj te na velike razlike između pojedinih odgojnih ustanova u različitim sredinama, što više ukazuje na nezadovoljstvo samom provedbom te odgojne mjere nego na nezadovoljstvo izricanjem.

Kod pridržaja kazne maloljetničkog zatvora ponovno postoji značajna razlika u percepciji zaposlenika svih triju institucija $(\mathrm{KW}=15.127$; $\mathrm{p}<.01)$. Post hoc analizom utvrđeno je da su zaposlenici državnih odvjetništava najmanje zadovoljni izricanjem ove sankcije, dok su zaposlenici sudova najviše zadovoljni. Takav podatak ne čudi s obzirom na to da je gotovo $45 \%$ ispitanika zaposlenih u državnom odvjetništvu na kvalitativnom dijelu pitanja odgovorilo kako ovom sankcijom nisu niti zadovoljni niti nezadovoljni ili da ne mogu procijeniti iz razloga što se ne izriče dovoljno često, dok je njih oko $14 \%$ odgovorilo kako ovom sankcijom uglavnom ili u potpunosti nisu zadovoljni, te kao glavni razlog nezadovoljstva navode izricanje pridržaja kazne maloljetničkog zatvora bez dodatne odgojne mjere. Posljednje ispitivano područje je zadovoljstvo kvalitetom izricanja sigurnosnih mjera. Iako su sve tri institucije u manjoj mjeri zadovoljne izricanjem sigurnosnih mjera, statistički značajne razlike u percepciji zaposlenika postoje između zaposlenika državnih odvjetništava i sudova, u smjeru da su zaposlenici državnih odvjetništava i u ovom slučaju manje zadovoljni, a kao razloge navode vrlo rijetko izricanje te poteškoće s praćenjem provedbe.

Važno je napomenuti kako su za sva područja na kojima postoji značajna razlika efekti tih razlika mali i kreću se od $0.12<\mathrm{r}<0.29$. Zbog toga se trebaju rezultati interpretirati s dodatnim oprezom, odnosno ne treba se donositi zaključke o postojanju velikih razlika u percepciji zaposlenika određenih institucija.

Posljednji ispitivani dio odnosi se na zadovoljstvo kvalitetom izvršavanja različitih maloljetničkih sankcija (Tablica 5.). 
Tablica 5.: Deskriptivni prikaz zadovoljstva kvalitetom izvršavanja maloljetničkih sankcija $(\mathrm{N}=309)$ i razlike u zadovoljstvu kvalitetom izvršavanja maloljetničkih sankcija s obzirom na ustanovu zaposlenja (Kruskal-Wallisov test i Mann-Whitneyev test kao post hoc test, uz efekt razlike)

\begin{tabular}{|c|c|c|c|c|c|c|c|c|c|c|c|c|c|c|}
\hline \multirow{2}{*}{$\begin{array}{c}\text { KVALITETA } \\
\text { IZVRŠAVANJA }\end{array}$} & \multirow{2}{*}{ USTANOVA } & \multirow{2}{*}{$N$} & \multicolumn{6}{|c|}{$\%$} & \multirow{2}{*}{$M$} & \multirow{2}{*}{$S D$} & \multirow{2}{*}{$P R$} & \multirow{2}{*}{$\boldsymbol{K} W$} & \multirow{2}{*}{$M W U$} & \multirow{2}{*}{$r$} \\
\hline & & & 0 & 1 & 2 & 3 & 4 & 5 & & & & & & \\
\hline \multirow{3}{*}{ Posebnih obveza } & CZSS & 129 & 8.5 & 0.8 & 7.0 & 24.0 & 48.1 & 11.6 & 3.37 & 1.299 & 146.46 & \multirow{3}{*}{3.454} & \multirow{3}{*}{ - } & \multirow{3}{*}{ - } \\
\hline & DO & 98 & 4.1 & 0.0 & 10.2 & 17.3 & 60.2 & 8.2 & 3.58 & .930 & 155.46 & & & \\
\hline & SUD & 82 & 3.7 & 0.0 & 2.4 & 24.4 & 53.7 & 15.9 & 3.72 & 1.010 & 167.88 & & & \\
\hline \multirow{3}{*}{$\begin{array}{l}\text { Upućivanja u } \\
\text { disciplinski } \\
\text { centar }\end{array}$} & CZSS & 129 & 24.0 & 0.8 & 5.4 & 27.1 & 34.1 & 8.5 & 2.72 & 1.695 & 151.83 & \multirow{3}{*}{.408} & \multirow{3}{*}{ - } & \multirow{3}{*}{ - } \\
\hline & DO & 98 & 12.2 & 4.1 & 5.1 & 38.8 & 30.6 & 9.2 & 2.99 & 1.418 & 159.17 & & & \\
\hline & SUD & 82 & 20.7 & 0.0 & 6.1 & 29.3 & 37.8 & 6.1 & 2.82 & 1.596 & 154.99 & & & \\
\hline \multirow{3}{*}{$\begin{array}{l}\text { PBIN kada je } \\
\text { provodi Centar }\end{array}$} & CZSS & 129 & 10.1 & 1.6 & 6.2 & 22.5 & 45.0 & 14.7 & 3.35 & 1.401 & 148.99 & \multirow{3}{*}{$6.884 *$} & \multirow{3}{*}{$\begin{array}{l}\text { CZSS }<\mathrm{DO}^{*} \\
\text { SUD }<\mathrm{DO}^{*}\end{array}$} & \multirow{3}{*}{$\begin{array}{l}0.13 \\
0.18\end{array}$} \\
\hline & DO & 98 & 1.0 & 1.0 & 4.1 & 18.4 & 62.2 & 13.3 & 3.80 & .837 & 172.74 & & & \\
\hline & SUD & 82 & 3.7 & 0.0 & 17.1 & 20.7 & 48.8 & 9.8 & 3.40 & 1.110 & 143.25 & & & \\
\hline \multirow{3}{*}{$\begin{array}{l}\text { PBIN kada je } \\
\text { provode vanjski } \\
\text { suradnici }\end{array}$} & CZSS & 129 & 10.1 & 0.8 & 4.7 & 24.8 & 48.8 & 10.9 & 3.34 & 1.343 & 151.02 & \multirow{3}{*}{$6.905^{*}$} & & \\
\hline & DO & 98 & 4.1 & 1.0 & 5.1 & 17.3 & 59.2 & 13.3 & 3.66 & 1.074 & 171.99 & & SUD $<$ DO $* *$ & 0.19 \\
\hline & SUD & 82 & 8.5 & 1.2 & 6.1 & 29.3 & 48.8 & 6.1 & 3.27 & 1.248 & 140.96 & & & \\
\hline PBIN uz & CZSS & 129 & 31.8 & 1.6 & 9.3 & 23.3 & 29.5 & 4.7 & 2.31 & 1.745 & 152.78 & & & \\
\hline $\begin{array}{l}\text { dnevni boravak } \\
\text { u odgoinoj }\end{array}$ & DO & 98 & 29.6 & 6.1 & 8.2 & 24.5 & 26.5 & 5.1 & 2.28 & 1.722 & 151.06 & 1.035 & - & - \\
\hline ustanovi & SUD & 82 & 29.3 & 0.0 & 4.9 & 26.8 & 34.1 & 4.9 & 2.51 & 1.737 & 163.21 & & & \\
\hline & CZSS & 129 & 10.9 & 6.2 & 9.3 & 32.6 & 36.4 & 4.7 & 2.91 & 1.369 & 149.34 & & & \\
\hline $\begin{array}{l}\text { Upućivanja u } \\
\text { odgoinu ustanovu }\end{array}$ & DO & 98 & 5.1 & 4.1 & 16.3 & 34.7 & 33.7 & 6.1 & 3.06 & 1.174 & 152.70 & 2.162 & - & - \\
\hline & SUD & 82 & 8.5 & 3.7 & 9.8 & 26.8 & 43.9 & 7.3 & 3.16 & 1.319 & 166.64 & & & \\
\hline & CZSS & 129 & 25.6 & 1.6 & 9.3 & 25.6 & 34.9 & 3.1 & 2.52 & 1.649 & 154.20 & & & \\
\hline posebnu odgojnu & DO & 98 & 18.4 & 3.1 & 9.2 & 38.8 & 28.6 & 2.0 & 2.62 & 1.454 & 153.84 & .107 & - & - \\
\hline & SUD & 82 & 22.0 & 6.1 & 6.1 & 28.0 & 32.9 & 4.9 & 2.59 & 1.633 & 157.65 & & & \\
\hline & CZSS & 129 & 14.0 & 7.8 & 10.9 & 27.1 & 29.5 & 10.9 & 2.83 & 1.547 & 153.47 & & & \\
\hline $\begin{array}{l}\text { Upucivanja u } \\
\text { dooini zavod }\end{array}$ & DO & 98 & 11.2 & 3.1 & 8.2 & 35.7 & 39.8 & 2.0 & 2.96 & 1.308 & 158.33 & .216 & - & - \\
\hline & SUD & 82 & 13.4 & 4.9 & 8.5 & 32.9 & 36.6 & 3.7 & 2.85 & 1.415 & 153.42 & & & \\
\hline & CZSS & 129 & 31.8 & 3.9 & 7.8 & 28.7 & 19.4 & 8.5 & 2.26 & 1.760 & 146.04 & & & \\
\hline maloljetničkog & DO & 98 & 20.4 & 2.0 & 5.1 & 39.8 & 29.6 & 3.1 & 2.65 & 1.514 & 164.78 & 2.718 & - & - \\
\hline & SUD & 82 & 23.2 & 6.1 & 7.3 & 30.5 & 29.3 & 3.7 & 2.48 & 1.612 & 157.40 & & & \\
\hline & CZSS & 129 & 17.1 & 0.0 & 7.8 & 28.7 & 34.9 & 11.6 & 2.99 & 1.564 & 159.79 & & & \\
\hline maloljetničkog & DO & 98 & 17.3 & 2.0 & 9.2 & 34.7 & 32.7 & 4.1 & 2.76 & 1.479 & 142.27 & 3.209 & - & - \\
\hline & SUD & 82 & 17.1 & 0.0 & 7.3 & 26.8 & 36.6 & 12.2 & 3.02 & 1.579 & 162.68 & & & \\
\hline & CZSS & 129 & 24.8 & 3.1 & 5.4 & 40.3 & 20.9 & 5.4 & 2.46 & 1.601 & 153.31 & & & \\
\hline Sigurnosnih & DO & 98 & 24.5 & 4.1 & 12.2 & 35.7 & 22.4 & 1.0 & 2.31 & 1.516 & 143.72 & 4.634 & - & - \\
\hline & SUD & 82 & 25.6 & 1.2 & 3.7 & 26.8 & 35.4 & 7.3 & 2.67 & 1.722 & 171.13 & & & \\
\hline
\end{tabular}


Legenda: N=uzorak sudionika; $0=$ ne mogu procijeniti; $1=$ =uopće nisam zadovoljan; $2=$ uglavnom nisam zadovoljan; $3=$ niti zadovoljan, niti nezadovoljan; $4=$ uglavnom sam zadovoljan; 5=u potpunosti sam zadovoljan; $\mathrm{M}=$ aritmetička sredina; $\mathrm{SD}=$ standardna devijacija; KW $\chi^{2}=$ Kruskal-Wallis Hi-kvadrat; MWU=Mann-Whitney U-test; $\mathrm{r}=$ veličina efekta; ${ }^{*} \mathrm{p}<.050 ;{ }^{* *} \mathrm{p}<.010 ; * * * \mathrm{p}<.001$

Iz prikazanih je rezultata vidljivo da statistički značajna razlika u zadovoljstvu izvršavanja maloljetničkih sankcija postoji samo kod izvršavanja PBIN-a. Na područjima na kojima ne postoje razlike, aritmetičke sredine kreću se od 2.26 do 3.80 (Tablica 5.), te pokazuju kako su sudionici svih triju institucija općenito manje do umjereno zadovoljni kvalitetom izvršavanja maloljetničkih sankcija. Uvidom u kvalitativni dio odgovora na tim područjima uočavaju se slični odgovori sudionika, bili oni pozitivni u smislu zadovoljstva izvršavanjem određenom sankcijom ili negativni, odnosno ukazujući na poteškoće izvršavanja sankcija. Primjerice, svi sudionici navode zadovoljstvo izvršavanjem posebnih obveza te komentiraju široki spektar istih unutar kojeg mogu djelovati. Naglašavaju dobru suradnju s institucijama u kojima se pojedine posebne obveze izvršavaju i komunikaciju sa stručnjacima. S druge strane, svi podjednako iskazuju manje zadovoljstvo kvalitetom izvršavanja PBIN-a uz dnevni boravak u odgojnoj ustanovi, uz obrazloženja kako se ta sankcija ne izriče, pa tako i ne izvršava dostatno, te kako u brojnim manjim mjestima nema uvjeta za njezino izvršavanje.

Kada je riječ o PBIN-u kada je provodi centar za socijalnu skrb, značajna razlika u percepciji postoji između zaposlenika centara za socijalnu skrb i državnih odvjetništava (MWU $=5376.0 ; \mathrm{p}<.05$ ) te između zaposlenika državnih odvjetništava i sudova za mladež (MWU=3224.5; $<<.05$ ). Točnije, zaposlenici centara za socijalnu skrb najmanje su zadovoljni izvršavanjem ove sankcije. U svojim komentarima objašnjavaju kako je ta sankcija dobra kada je provode vanjski suradnici, no kada je provode djelatnici centra, dolazi do preopterećenosti djelatnika zbog ostalih poslova koje obavljaju i shodno tomu, u mnogim slučajevima imaju malo vremena za njezinu provedbu. Drugim riječima, sudionici su zadovoljni sankcijom, no zbog vlastite preopterećenosti, nisu zadovoljni izvršavanjem ako je ono povjereno njima. Zaposlenici državnih odvjetništava u tom su slučaju najzadovoljniji izvršavanjem ove sankcije, te naglašavaju kako kvaliteta izvršavanja ponajviše ovisi o angažmanu, trudu i stručnosti voditelja mjere.

U PBIN-u kada je provode vanjski suradnici postoji statistički značajna razlika u zadovoljstvu izvršavanja među zaposlenicima državnih odvjetništava i sudova (MWU $=3197.5 ; \mathrm{p}<.01$ ), tako da su zaposlenici sudova manje zadovoljni kvalitetom izvršavanja ove sankcije (pri čemu je važno naglasiti da je veličina efekata relativno niska). Kvalitativni odgovori ističu važnost kvalitete vanjskog suradnika, odnosno kako kvaliteta izvršavanja ove sankcije uvelike ovisi o obilježjima i sposobnostima vanjskih suradnika - drugim riječima provoditeljima (voditeljima) mjere. Ono što zaposlenici sudova navode kao razloge nezadovoljstva jest činjenica da u manjim mjestima nema dostatno stručnih i kvalitetnih osoba koje bi bile vanjski suradnici, a i centri za socijalnu skrb u manjim mjestima nemaju potrebe za vanjskim suradnicima. Općenito se može reći kako se svi stručnjaci koji rade u sustavu maloljetničkog 
pravosuđa suočavaju sa sličnim ili istim problemima pri izvršavanju određenih sankcija prema maloljetnicima, a u većini slučajeva to se odnosi na nedostatak resursa u manjim mjestima u kojima se pojedine sankcije u zajednici (alternativne sankcije) mogu kvalitetno izvršavati.

\section{ZAKLJUČAK I SMJERNICE ZA DALJNJA ISTRAŽIVANJA}

Nedvojbeno je da je kvalitetna suradnja jedan od najvažnijih čimbenika u osiguravanju svrhovitosti postupka prema maloljetnicima i preveniranju njihova daljnjeg činjenja kaznenih djela. U Hrvatskoj su ključni dionici u tom postupku centri za socijalnu skrb, državna odvjetništva i sudovi za mladež. Upravo je zato iznimno važna njihova perspektiva i doživljaj različitih aspekata funkcioniranja maloljetničkog pravosuđa. Naime, za pretpostaviti je da su spomenuti stručnjaci oni koji najbolje znaju procijeniti kvalitetu sadržaja različitih zakonskih propisa i njihovu neposrednu provedbu u praksi. Nadalje, s obzirom na njihovu svakodnevnu uključenost u postupke prema maloljetnicima u različitim fazama, imaju dobar uvid u izvršavanje sankcija te mogućnosti i potencijale unaprjeđivanja sustava. Zbog svega navedenoga, Povjerenstvo za praćenje i unaprjeđivanje rada tijela kaznenog postupka i izvršavanja maloljetničkih sankcija koje djeluje pri Ministarstvu pravosuđa Republike Hrvatske iniciralo je ovo istraživanje, kako bi se identificirali primjeri dobre prakse, kao i izazovi u području maloljetničkog pravosuđa, čiji je dio prikazan u ovom radu.

Iz rezultata se može zaključiti kako su stručnjaci uglavnom zadovoljni funkcioniranjem maloljetničkog pravosuđa u cjelini, no razumljivo, vide i prostor za unaprjeđenje te su utvrđene određene razlike s obzirom na područje rada. Osvrnemo li se na postavljenu hipotezu ovog istraživanja, možemo je djelomično potvrditi.

Naime, iako razlike u doživljaju različitih aspekata maloljetničkog pravosuđa s obzirom na područje rada nisu jako velike, promatrajući općenito, stručnjaci zaposleni u državnim odvjetništvima najkritičniji su prema sustavu (zamjenici općinskih i županijskih državnih odvjetnika za mladež i stručni suradnici izvanpravne struke na državnim odvjetništvima), dok stručnjaci sa sudova sustav procjenjuju pozitivnije. Nadalje, potvrđen je i zanimljiv, a opet i razumljiv trend smanjivanja zadovoljstva svih sudionika približavanjem praktičnim aspektima rada, odnosno primjeni i provedbi pravnih propisa. Točnije, sudionici su najviše zadovoljni načelima maloljetničkog pravosuđa i sadržajem zakonskih propisa povezanih s postupanjem prema maloljetnicima, dok su manje zadovoljni izricanjem, a najkritičniji su u odnosu na izvršavanje maloljetničkih sankcija. Takvi rezultati još jednom govore u prilog činjenici da su načela i zakonski propisi vezani za maloljetničko pravosuđe kvalitetno i dobro propisani, no da je praktična provedba i dalje opterećena određenim izazovima.

U tom smislu, sudionici naglašavaju neusklađenost zakona i prakse, navodeći kako zakon nudi širok spektar maloljetničkih sankcija koje se mogu izreći maloljetnim počiniteljima kaznenih djela, ali problem je što ih nije uvijek moguće (kvalitetno) izvršavati. To se najčešće odnosi na nedostatak resursa u manjim lokalnim zajednicama u kojima bi se mogle izvršavati neke posebne obveze, ali i odgojna mjera pojačane brige i nadzora uz dnevni boravak u odgojnoj ustanovi. 
Također očekivano, stručnjaci su više zadovoljni maloljetničkim sankcijama koje se izvršavaju u zajednici u odnosu na one institucionalne. Kada je riječ o problemima povezanim s izvršavanjem institucionalnih sankcija, glavni je izvor nezadovoljstva stručnjaka nejasna i nedovoljna diferencijacija tretmana, loši uvjeti izvršavanja sankcija (stambeni uvjeti, nedovoljno sadržaja koji se nude maloljetnicima i sl.) te nepostojanje takvih ustanova u nekim dijelovima Hrvatske. Loše stambene uvjete sudionici su posebno naglašavali za Odgojni zavod u Turopolju, zbog čega je ta sankcija bila rjeđe izricana, pa samim time i izvršavana. Pritom je važno naglasiti da se tijekom 2017. godine infrastruktura odgojnog zavoda u potpunosti promijenila

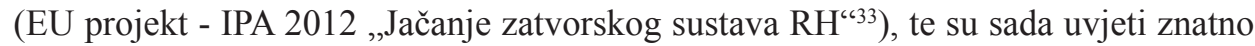
kvalitetniji nego u vrijeme provođenja ovog istraživanja. U tom je smislu za očekivati da će posljedično zadovoljstvo ovom mjerom u budućnosti biti veće, ali navedeno je svakako potrebno provjeriti daljnjim istraživanjima.

S druge strane, svi su stručnjaci relativno zadovoljni kvalitetom izvršavanja maloljetničkih sankcija koje se izvršavaju u zajednici. Posebno ističu odgojnu mjeru pojačane brige i nadzora kada je provode vanjski suradnici, a kao glavne izvore zadovoljstva navode kvalitetnu komunikaciju i intenzivan angažman vanjskih suradnika. Stručnjaci u sustavu pravosuđa u velikoj su mjeri zadovoljni kvalitetom izvršavanja PBIN-a kada je provode zaposlenici centara za socijalnu skrb, dok oni sami smatraju da imaju nedovoljno vremenskog kapaciteta za kvalitetan rad. Informacije dobivene ovim istraživanjem vrijedne su u kontekstu promišljanja i planiranja praktičnih unaprjeđenja, ali nude i važne znanstvene implikacije.

Što se tiče praktičnih implikacija, ovim su istraživanjem identificirana područja u koja je potrebno dodatno ulagati. Konkretno, rezultati nedvojbeno govore $\mathrm{u}$ prilog potrebe za unaprjeđenjem cijelog sustava kako bi se osiguralo djelovanje $u$ skladu s načelima maloljetničkih sankcija i u skladu s elementima uspješne prakse (i sankcija u zajednici i onih u instituciji). Sudionici istraživanja suglasni su i da je neophodno organizirati i provoditi sustavne edukacije stručnjaka specijalizirane za maloljetničko pravosuđe o mogućnostima koje imaju na raspolaganju pri izricanju sankcija, s obzirom na to da rezultati pokazuju kako se neke odgojne mjere manje izriču zbog nedovoljnog poznavanja tretmanskih specifičnosti različitih sankcija, ali i institucija u okviru kojih se izvršavaju. To, pak, vodi i do sljedećeg izazova, a to je nedovoljna diferencijacija tretmana, posebno onog institucionalnog. U tom je smislu neophodno sustavno ulagati u ustanove socijalne skrbi u kojima se izvršavaju takve maloljetničke sankcije, unaprjeđivati kvalitetu tretmana te ga sustavno sistematizirati i diferencirati. Vidljivo je i da se potencijali nekih sankcija gotovo u potpunosti ne koriste. Tako, primjerice, veliki broj sudionika navodi da nema iskustvo s izricanjem i/ili izvršavanjem sigurnosnih mjera, no ona manjina kod koje to nije slučaj, izvještava o velikom zadovoljstvu i koristi spomenutih mjera. Potom, tu je i očekivani problem $\mathrm{s}$ izvršavanjem odgojne mjere upućivanja u posebnu odgojnu ustanovu gdje veliki broj stručnjaka navodi kako nema iskustvo s ovom tom mjerom. Uzme li se u obzir da se gotovo svi dionici sustava slažu kako Centar za odgoj i obrazovanje Lug (kao

33 Vidi: https://pravosudje.gov.hr/pristup-informacijama-6341/ostale-informacije/projekti/euprojekti/ipa-2012-jacanje-zatvorskog-sustava-rh/9973 (pristupljeno 1. ožujka 2018.). 
trenutačno jedina ustanova u zemlji u kojoj se izvršava odgojna mjera upućivanja $u$ posebnu odgojnu ustanova) nije dovoljan, te da ne postoji dovoljno specifičan tretman za mlade počinitelje kaznenih djela koji imaju i probleme mentalnog zdravlja, ovakav rezultat ne iznenađuje.

Što se standarda kvalitete tiče, stručnjaci su posebno nezadovoljni činjenicom da oni nisu sustavno razvijeni niti ujednačeni u svim dijelovima Hrvatske. Primjerice, u nekim manjim lokalnim sredinama ne postoje resursi za provedbu dijela zakonski propisanih posebnih obveza, kao što je i evidentan manjak vanjskih suradnika koji bi provodili PBIN (što se čini važnim posebno uzevši u obzir da su najzadovoljniji upravo provedbom PBIN-a kada je provode vanjski suradnici). U tom je smislu važno napore usmjeriti prema kreiranju standarda kvalitete za sve maloljetničke sankcije, educiranje cijele linije stručnjaka zaposlenih u sustavu, ali i vanjskih suradnika.

U kontekstu znanstvenih implikacija, ovim smo istraživanjem odgovorili samo na dio istraživačkih problema. U budućim bi istraživanjima svakako bilo vrijedno dobivene rezultate produbiti, te ih (uz iskustva iz prakse te rezultate drugih istraživanja) iskoristiti za stvaranje znanstveno-utemeljenih smjernica za unaprjeđenje maloljetničkog pravosuđa u našoj zemlji. Ako se sustavno, multidisciplinarno i uz uključivanje svih bitnih dionika, pristupi ovoj temi osigurat će se preduvjeti za unaprjeđenje cijelog sustava usmjerenog maloljetnim počiniteljima kaznenih djela, kako bi se pružila što kvalitetnija, adekvatnija i cjelovitija intervencija, a u konačnici unaprijedilo i društvo u cjelini.

\section{LITERATURA}

1. Carić, A. i Kustura, I., Kamo ide hrvatsko maloljetničko kazneno zakonodavstvo? - 1 . dio, Zbornik radova Pravnog fakulteta u Splitu, vol. 47, br. 3, 2010a, str. 605-620.

2. Carić, A., Kustura, I., Kamo ide hrvatsko maloljetničko kazneno zakonodavstvo? - 2. dio, Zbornik radova Pravnog fakulteta u Splitu, vol. 47, br. 4, 2010b, str. 779-820.

3. ChildONEurope (2013), Complementarities and synergies between juvenile justice and social services sector: The proceedings of the ChildONEurope Seminar on Juvenile Justice, objavljeno na: <http://www.childoneurope.org/issues/publications/coe\%206 web.pdf>, zadnji put posjećeno 5. studenog 2016.

4. Kazneni zakon, NN 125/2011., 144/2012., 56/2015., 61/2015., 101/2017.

5. Konvencija o pravima djeteta (1989), objavljeno na: $<$ https://www.unicef.hr/wp-content/ uploads/2017/05/Konvencija_20o_20pravima_20djeteta_full.pdf $>$, zadnji put posjećeno 1. ožujka 2018.

6. Kovačević, M., Osnovni modeli maloljetničkog pravosuđa s osvrtom na ulogu i položaj socijalnog rada, Ljetopis socijalnog rada, vol. 20, br. 2, 2013, str. 301-317.

7. Murphy, P., McGinnes, A., McDermott, T. (2010), Review of Effective Practice in Juvenile Justice, Report for the Minister for Juvenile Justice, Noetic Solutions Pty Limited, Manuka, Australia, objavljeno na: $<\mathrm{http}: / / w w w . j u v e n i l e . j u s t i c e . n s w . g o v . a u / D o c u m e n t s /$ Juvenile\%20Justice\%20Effective\%20Practice\%20Review\%20FINAL.pdf $>$, zadnji put posjećeno 10. ožujka 2018.

8. Nacionalna strategija za prava djece u Republici Hrvatskoj za razdoblje od 2014. do 2020. godine (2014), Ministarstvo socijalne politike i mladih, objavljeno na: $<$ https:// vlada.gov.hr/UserDocsImages/ZPPI/Strategije\%20-\%20OGP/socijalna\%20politika/ NACIONALNA\%20STRATEGIJA\%20ZA\%20PRAVA\%20DJECE\%20U\%20 
RHZA\%20RAZDOBLJE\%20OD\%202014.\%20DO\%202020.\%20GODINE\%5B1\%5D. pdf $>$, zadnji put posjećeno 1. ožujka 2018.

9. Pravila Ujedinjenih naroda za zaštitu maloljetnika lišenih slobode („Pravila iz Havane“, 1990), (A/RES/45/113), objavljeno na: <http://www.un.org/documents/ga/res/45/ a45r113.htm>, zadnji put posjećeno 1. ožujka 2018.

10. Pravilnik o načinu izvršavanja odgojnih mjera posebne obveze, upućivanje u disciplinski centar, pojačana briga i nadzor, pojačana briga i nadzor uz dnevni boravak u odgojnoj ustanovi, upućivanje u odgojnu ustanovu i upućivanje u posebnu odgojnu ustanovu, NN 141/2011., 21/2012.

11. Pravilnik o radu stručnih suradnika izvanpravne struke na poslovima delinkvencije mladih i kaznenopravne zaštite djece u državnim odvjetništvima i na sudovima, NN 22/2013.

12. Radić, I., Hrvatski sustav maloljetničkih sankcija: trenutačno stanje i prijedlozi za promjenu, Hrvatski ljetopis za kaznene znanosti i praksu, vol. 24, br. 1, 2017, str. 83-115.

13. Ricijaš, N., Dobre prakse i izazovi u kontekstu maloljetničke delinkvencije u Hrvatskoj, objavljeno u Kovačević, R. i sur. (ur.): Maloljetnička delinkvencija - dijalog, razmjena iskustava i znanja, OFF SET Tuzla, Bosna i Hercegovina, 2017, str. 123-144.

14. Ricijaš, N., Pravo maloljetnika na primjeren tretman u izvršavanju alternativnih sankcija, objavljeno u Vladović, $\mathrm{S}$. (ur.): Zaštita prava i interesa djece s problemima u ponašanju: Zbornik priopćenja sa stručnih skupova pravobraniteljice za djecu, Pravobranitelj za djecu, Zagreb, 2012, str. 245-257.

15. Ricijaš, N., Priručnik za edukaciju - Procjena, planiranje i izvještavanje u izvršavanju maloljetničkih alternativnih sankcija, Zagreb, Ministarstvo socijalne politike i mladih, 2012.

16. Ricijaš, N., Jeđud Borić, I., Lotar Rihtarić, M. (2014), Pojačana briga i nadzor iz perspektive mladih i voditelja mjere, UNICEF Ured za Hrvatsku, Zagreb, objavljeno na: <https://www.unicef.hr/wp-content/uploads/2015/09/PBIN_publikacija_web.pdf>, zadnji put posjećeno 1. ožujka 2018.

17. Rittossa, D., Božićević Grbić, M., Zakon o sudovima za mladež - reformski zahvati i praktične dileme, Hrvatski ljetopis za kazneno pravo i praksu, vol. 19, br. 2, 2012, str. 615-667.

18. Singer, M., Kaznenopravna odgovornost i zaštita mladeži, Zagreb, Nakladni zavod Globus i Sveučilište u Zagrebu, 1998.

19. Smjernice Odbora ministara Vijeća Europe o pravosuđu prilagođenom djeci, objavljeno na: <https://rm.coe.int/16806a450a>, zadnji put posjećeno 1. ožujka 2018.

20. Smjernice Ujedinjenih naroda za prevenciju maloljetničke delinkvencije („Rijadske smjernice“, 1990), (A/RES/45/112), objavljeno na: <http://www.un.org/documents/ga/ res/45/a45r112.htm>, zadnji put posjećeno 1. ožujka 2018.

21. Standardna minimalna pravila Ujedinjenih naroda za maloljetničko pravosuđe („Pekinška pravila“, 1985), (A/RES/40/33), objavljeno na: <http:/www.un.org/documents/ga/res/40/ a40r033.htm>, zadnji put posjećeno 1. ožujka 2018.

22. Štabi, M., Standardna minimalna pravila Ujedinjenih Naroda za maloljetničko pravosuđe („Pekinška pravila“, 1985) (A/RES/40/33) i Smjernice Ujedinjenih naroda za prevenciju maloljetničke delinkvencije („Rijadske smjernice“, 1990) (A/RES/45/112), Dijete i društvo: časopis za promicanje prava djeteta, vol. 12, br. 1/2, 2010, str. 295-296.

23. Ustav Republike Hrvatske, NN 56/1990., 135/1997., 8/1998., 113/2000., 124/2000., 28/2001., 41/2001., 55/2001., 76/2010., 85/2010., 05/2014.

24. Zakon o izvršavanju sankcija izrečenih maloljetnicima za kaznena djela i prekršaje, NN $133 / 2012$.

25. Zakon o kaznenom postupku, NN 152/2008., 76/2009., 80/2011., 121/2011., 91/2012., 143/2012., 56/2013., 145/2013., 152/2014, 70/2017.

26. Zakon o potvrđivanju Europske konvencije o ostvarivanju dječjih prava, NN 1/2010.

27. Zakon o sudovima za mladež, NN 84/2011., 143/2012., 148/2013., 56/2015. 


\author{
Sabina Mandić* \\ Dora Dodig Hundrić** \\ Neven Ricijaš $* * *$ \\ Mirta Kuharić $* * * *$
}

Summary

\title{
THE VIEW OF EXPERTS ON THE EFFECTIVENESS OF THE JUVENILE JUSTICE SYSTEM
}

This paper presents part of the results of the study conducted within the Committee for monitoring and improving the work of criminal proceedings and the execution of juvenile sanctions in the Croatian Ministry of Justice, founded according to Article 127. Paragraph 1. of the Youth Courts Act. Study focuses on the perception of judiciary and interdepartmental cooperation between State Attorney's Offices, Youth Courts and Centers for Social Welfare in criminal proceedings towards juvenile criminal offenders. In this paper, the emphasis is on the part of the results aimed at different aspects of the juvenile justice. The main aim is to gain insight into the experts' perspective of the effectiveness and purposefulness of the juvenile justice system, and to explore possible differences in their perception with regard to the field of work. A total of $n=309$ professionals participated in this study, $n=98$ of which work in State Attorney's Office, $n=82$ at Youth Courts and $n=129$ in the Centers for Social Welfare.

The results indicate general moderate satisfaction with the functioning of the juvenile justice system, especially it's legal principles and content of the law regulations, as well as conducting community educational measures. Participant are the least satisfied with the execution of half-institutional and institutional sanctions, especially professionals working in the State Attorney's Offices who seem to have the most critical attitudes towards the system, especially when compared with the employees of the youth courts.

The results provide the basis for further research and are interpreted in order

* Sabina Mandić, mag. paed. soc., Research and Teaching Assistant, Department of Behavioural Disorders, Faculty of Education and Rehabilitation Sciences, University of Zagreb; sabina. mandic@erf.hr.

** Dora Dodig Hundrić, Ph. D., Assistant Professor, Department of Behavioural Disorders, Faculty of Education and Rehabilitation Sciences, University of Zagreb; dora.dodig@erf.hr.

*** Neven Ricijaš, Ph. D., Associate Professor, Department of Behavioural Disorders, Faculty of Education and Rehabilitation Sciences, University of Zagreb; member of Committee for monitoring and improving the work of criminal proceedings and the execution of juvenile sanctions; neven.ricijas@erf.hr.

**** Mirta Kuharić, dipl. iur., Deputy State Attorney General of the Republic of Croatia; Chairman of Committee for monitoring and improving the work of criminal proceedings and the execution of juvenile sanctions; mirta.kuharic@dorh.hr. 
to discuss possible further implications and the possibility of improving the system.

Keywords: Juvenile Justice System, Youth Courts Act, Centre for Social Welfare, State Attorney's Office, Youth Court.

Zussamenfassung

\section{DIE ANSICHT VON EXPERTEN ÜBER DIE ZWECKMÄSSIGKEIT DES SYSTEMS DER JUGENDGERICHTSBARKEIT}

In diesem Beitrag wird ein Teil der Ergebnisse der von dem Ausschuss für die Kontrolle und die Verbesserung der Arbeit von Organen des Strafverfahrens und des Vollzugs von Jugendsanktionen durchgeführten Forschung dargestellt. Der Ausschuss wurde gemäß Art. 127 Abs. 1 des Gesetzes über Jugendgerichte vom Justizminister begründet und dessen Ziel ist es, die Einsicht in die Perzeption des Justizsystems und die ressortübergreifende Zusammenarbeit zwischen den Staatsanwaltschaften, den Jugendgerichten und den Zentren für Sozialfürsorge bei den Strafverfahren gegen minderjährige Straftäter zu ermöglichen. Dieser Beitrag berichtet über einen Teil der Ergebnisse bezüglich verschiedener Aspekte der Jugendgerichtsbarkeit. Das Hauptziel des Beitrags ist es, die Einsicht in die Zweckmäßigkeit des Systems der Jugendgerichtsbarkeit aus der Perspektive von Experten zu geben sowie auch eventuelle Unterschiede in ihren Auffassungen, welche auf ihre unterschiedliche Arbeitsbereiche zurückzuführen sind, zu erforschen. Die Probe besteht aus 309 Befragten aus dem ganzen Kroatien, wobei 98 der Befragten in Staatsanwaltschaften, 82 der Befragten bei Gerichten und 129 der Befragten in den Zentren für Sozialfürsorge arbeiten.

Die Ergebnisse weisen darauf hin, dass die Befragten mit der Funktionierung der Jugendgerichtsbarkeit mäßig zufrieden sind und dass sie das kroatische System positiv auffassen, insbesondere bezüglich der grundlegenden Prinzipien und des Inhalts der Gesetzesvorschriften sowie auch bezüglich der Verhängung/des Vollzugs von außerinstitutionellen Erziehungsmaßnahmen. Am wenigsten zufrieden sind sie mit der Verhängung/dem Vollzug von halbinstitutionellen und institutionellen Sanktionen gegen Minderjährige, wobei die Befragten aus der Staatsanwaltschaft die schärfste Kritik diesbezüglich äußern, insbesondere gegenüber den Angestellten der Jugendgerichte.

Die Ergebnisse wurden im Kontext von potentiellen praktischen Auswirkungen und der Verbesserung des Systems interpretiert. Die Ergebnisse können auch als Grundlage für das weitere Forschen dieser Problematik dienen.

Schlüsselwörter: Jugendgerichtsbarkeit, Gesetz über Jugendgerichte, Zentrum für Sozialfürsorge, Staatsanwaltschaft, Jugendgerichte. 
Riassunto

\section{LA PERCEZIONE DEI PROFESSIONISTI CIRCA L'ADEGUATEZZA DEL SISTEMA DELLA GIUSTIZIA MINORILE}

In questo lavoro è illustrata parte dei risultati della ricerca promossa dalla Commissione per il monitoraggio ed il miglioramento dell'operato degli organi della procedura penale e dell'esecuzione delle sanzioni minorili costituita dal Ministro competente per gli affari della giustizia ai sensi dell'art. 127, comma 1, legge sui tribunali della gioventù, al fine di prendere visione della percezione del sistema giudiziario e della collaborazione tra pubblici ministeri, tribunali della gioventù e dei centri per la tutela sociale nei procedimenti penali instaurati contro minori che abbiano commesso reati penali. In questo lavoro l'accento è posto sulla parte dei risultati rivolti verso i diversi aspetti del funzionamento della giustizia minorile. Lo scopo principale del lavoro è entrare nella prospettiva dei professionisti circa l'adeguatezza del sistema della giustizia minorile ed eventualmente investigare sulle eventuali diversità nella loro percezione in ragione del diverso ambito di lavoro. L'indagine è stata condotta su un campione di 309 partecipanti provenienti da tutta la Croazia, di cui 98 impiegati nelle procure, 82 nei tribunali e 129 nei centri per la tutela sociale.

I risultati mostrano una contenuta soddisfazione circa il funzionamento della giustizia minorile ed una percezione positiva del sistema croato, in particolare negli aspetti riguardanti i principi generali ed il contenuto delle norme giuridiche, come anche negli aspetti riguardanti la comminazione e l'esecuzione di misure educative non istituzionali. Il grado di soddisfazione più basso riguarda l'ambito della comminazione e dell'esecuzione delle sanzioni minorili semi-istituzionali ed istituzionali, nel quale ambito gli appartenenti alle strutture delle procure manifestano il grado più basso di soddisfazione, ovvero esprimono la posizione maggiormente critica, in particolare con riguardo agli operatori dei tribunali della gioventù.

I risultati sono stati interpretati nel contesto delle potenziali implicazioni pratiche e della possibilità di miglioramento del sistema, come pure al fine di condurre nuove ricerche in merito.

Parole chiave: giustizia minorile, legge sui tribunali della gioventù, centro per la tutela sociale, pubblico ministero, tribunale della gioventù. 